\title{
Highly selective Diels-Alder and Heck arylation reactions in a divergent synthesis of isoindolo- and pyrrolo-fused polycyclic indoles from 2-formylpyrrole
}

\author{
Carlos H. Escalante ${ }^{1}$, Eder I. Martínez-Mora ${ }^{1,2}$, Carlos Espinoza-Hicks ${ }^{3}$, \\ Alejandro A. Camacho-Dávila ${ }^{3}$, Fernando R. Ramos-Morales ${ }^{4}$, Francisco Delgado ${ }^{1}$ \\ and Joaquín Tamariz ${ }^{* 1}$
}

\section{Full Research Paper}

\section{Address:}

1Departamento de Química Orgánica, Escuela Nacional de Ciencias Biológicas, Instituto Politécnico Nacional, Prolongación de Carpio y Plan de Ayala S/N, 11340 Mexico City, Mexico, ${ }^{2}$ Departamento de Química Orgánica, Facultad de Ciencias Químicas, Universidad Autónoma de Coahuila, Blvd. Venustiano Carranza e Ing. J. Cárdenas S/N, 25280 Saltillo, Coah., Mexico, ${ }^{3}$ Departamento de Química Orgánica, Facultad de Ciencias Químicas, Universidad Autónoma de Chihuahua, Circuito Universitario S/N, 31125 Chihuahua, Chih. Mexico and ${ }^{4}$ Unidad de Servicios de Apoyo en Resolución Analítica, Universidad Veracruzana, Luis Castelazo Ayala S/N, 91190 Xalapa, Ver., Mexico

Email:

Joaquín Tamariz - jtamarizm@gmail.com

* Corresponding author

Keywords:

endo-Diels-Alder stereocontrol; 2-formylpyrrole; intramolecular Heck arylation reaction; non-covalent interactions; pyrroloindoles; pyrroloisoindoles

\author{
Beilstein J. Org. Chem. 2020, 16, 1320-1334. \\ doi:10.3762/bjoc. 16.113
}

Received: 05 April 2020

Accepted: 28 May 2020

Published: 17 June 2020

Associate Editor: B. Stoltz

(C) 2020 Escalante et al.; licensee Beilstein-Institut.

License and terms: see end of document.

\footnotetext{
Abstract

A highly regio-, chemo- and stereoselective divergent synthesis of isoindolo- and pyrrolo-fused polycyclic indoles is herein described, starting from 2-formylpyrrole and employing Diels-Alder and Heck arylation reactions. 3-( $N$-Benzyl-2-pyrrolyl)acrylates and 4-(pyrrol-2-yl)butenones underwent a highly endo-Diels-Alder cycloaddition with maleimides to furnish octahydropyrrolo[3,4$e$ ]indoles, which served as precursors in the regioselective synthesis of aza-polycyclic skeletons via an intramolecular Heck arylation reaction. Through the latter reaction, the 3-( $N$-benzyl-2-pyrrolyl)acrylates give rise to 3-(pyrrolo[2,1- $a$ ] isoindol-3-yl)acrylates. A further oxidative aromatization of the polycyclic intermediates provides the corresponding polycyclic pyrrolo-isoindoles and isoindolo-pyrrolo-indoles. A theoretical study on the stereoselective Diels-Alder reactions, carried out by calculating the endo/exo transition states, revealed the assistance of non-covalent interactions in governing the endo stereocontrol.
} 


\section{Introduction}

Pyrrolizines [1,2] and pyrrolizidines [3,4], abundant in nature $[4,5]$, are among the simplest pyrrole-fused heterocyclic azabridged compounds. The numerous series of pyrrolizine-containing polycycles include pyrrolo[2,1-a]isoindoles [6], pyrrolo[1,2-a]indoles [7-10] and isoindolo[2,1-a]indoles [11] (Figure 1). These three series constitute the core of natural occurring alkaloids that are known to have varied and robust pharmacological activity, such as isoborreverine (1) [12], mitomycin A (2) [13] and chlorizidine A (3) [14]. The indole moiety is incorporated into their structure, which is important because it is a seminal heterocycle that exhibits a wide range of biological activity $[15,16]$ and great diversity as building block $[17,18]$.

Among the tetracyclic scaffolds, isoindolo[2,1-a]indoles have attracted a particular interest from the synthetic point of view, either as the target or the motif for designing novel annulation methodologies [19-21]. Indeed, isoindole-based heterocycles represent a varied and ubiquitous scaffold found in a large number of natural and synthetic bioactive compounds [22-25], such as isoindolocarbazoles (e.g., arcyriaflavins A-C (4a-c)) $[26,27]$.
The challenge of the synthesis of this series of aza-heterocycles is associated with the complexity of its structures [11,19-27]. The intramolecular Heck arylation coupling reaction is among the most useful strategies for the construction of these compounds (Scheme 1) [11,21]. For example, isoindolo[2,1$a$ ]indoles 6 have been prepared by the annulation process through a $\mathrm{Pd}$ - or Ni-catalyzed coupling starting from the $N$-functionalized indoles 5 [11,19,21,28-30]. On the other hand, the formation of pyrrolo[3,4-e]indoles $\mathbf{9 / 1 0}$ can be achieved via a Diels-Alder cyloaddition of 2-vinylpyrroles 8 with maleimides 7 [31-35]. This is a representative example of the less common approach for the construction of the indole skeleton on substituted pyrroles by generating the benzene ring via an annulation process [36-39].

Due to our interest in transforming simple five-membered heterocycles into natural products $[40,41]$ and complex azapolycyclic structures [42], we herein combined both approaches shown in Scheme 1 to design the construction of pentacycles 11, after carrying out an uncommon but highly diastereoselective Diels-Alder cycloaddition followed by a coupling reaction. This route also allowed out the aromatization of<smiles>c1ccc2c(c1)Cn1cccc1-2</smiles>

$5 H$-pyrrolo[2,1-a]isoindole<smiles>CNCCc1c([C@H]2[C@H]3CC(C)=CC(C)(C)[I-]3c3c(CCNC)c4ccccc4n32)[nH]c2ccccc12</smiles>

isoborreverine (1)<smiles>O=C1c2c(cc(O)c([C@H]3CCc4cc(Cl)c(Cl)n43)c2O)-c2cc(Cl)c(Cl)n21</smiles>

chlorizidine A (3)<smiles>C1=Cn2c(cc3ccccc32)C1</smiles>

$1 H$-pyrrolo[1,2-a]indole<smiles>c1ccc2c(c1)Cn1c-2cc2ccccc21</smiles>

$6 \mathrm{H}$-isoindolo[2,1-a]indole<smiles></smiles>

mitomycin A (2)<smiles></smiles>

arcyriaflavin $A\left(4 a, R=R^{\prime}=H\right)$ arcyriaflavin $B\left(4 b, R=O H, R^{\prime}=H\right)$ arcyriaflavin $\mathrm{C}\left(\mathbf{4 c}, \mathrm{R}=\mathrm{R}^{\prime}=\mathrm{OH}\right)$ 
<smiles>[R]c1ccc2c(c1)C([Y])n1c-2cc2ccccc21</smiles>

6, $\mathrm{Y}=\mathrm{H}_{2}, \mathrm{O}$<smiles></smiles>

5, $\mathrm{X}=\mathrm{Br}, \mathrm{I} ; \mathrm{Y}=\mathrm{H}_{2}, \mathrm{O}$<smiles>[R][R]1ccc2c(c1)Cn1c-2cc2c1CC([R])C1C(=O)N([R])C(=O)C21</smiles>

11<smiles>[R]C=Cc1cccn1[R]</smiles><smiles>[R]c1cc2c3cc1C(=O)C(=O)c1cccc4c1cc(n4C3)C2=O</smiles>

12

Scheme 1: Synthetic approaches for the preparation of pyrrolo-fused aza-hetero polycyclic frames.

the $\mathrm{B}$ ring to provide compounds $\mathbf{1 2}$. To account for the strong endo preference of adducts $\mathbf{9}$, a computational study was performed to analyze the stationary points on the potential surfaces of the Diels-Alder reactions.

\section{Results and Discussion}

\section{Synthesis}

Pyrroles 8a-j were prepared through a straightforward and efficient route based on the functionalization of 2-formylpyrrole (13a), using recently described methodologies [41]. Firstly, 13a was reacted with the series of benzyl bromides $14 \mathbf{a}-\mathbf{d}$ to produce adequately $N$-substituted five-membered aza-units 13b-e, respectively (Scheme 2 ), which were treated with the phosphonates 15a-c to afford derivatives 8a-f in high yields (Table 1, entries 1-6). For the synthesis of pyrroles $\mathbf{8 g}, \mathbf{h}\left(\mathrm{R}^{1}=\right.$ Ac), pyrroles $13 \mathrm{c}$ and $13 \mathrm{e}$ were subjected to condensation reactions at a higher temperature, with acetone as the nucleophile (instead the phosphonate 15) in the presence of $\mathrm{KOH}$ as the base (Table 1, entries 7 and 8). The second methodology consisted of an inverted sequence of reactions in relation to the

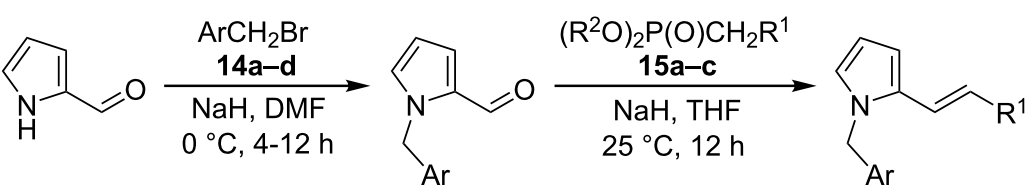

$13 a$

13b, $\mathrm{Ar}=\mathrm{Ph}(99 \%)$

8a-f

\section{$15 a, b$}

13c, $\mathrm{Ar}=\mathrm{C}_{6} \mathrm{H}_{4}-2-\mathrm{Br}(96 \%)$

$\mathrm{NaH}, \mathrm{THF}$ $0-25 \hat{A}^{\circ} \mathrm{C}, 1-2 \mathrm{~h}$

13e, $\mathrm{Ar}=\mathrm{C}_{6} \mathrm{H}_{2}-2-\mathrm{Br}-4,5-(\mathrm{OMe})_{2}(97 \%)$<smiles>[R]C=Cc1ccc[nH]1</smiles>

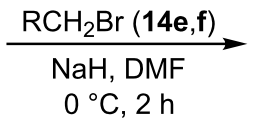

16a, $\mathrm{R}^{1}=\mathrm{CO}_{2} \mathrm{Me}(93 \%)$

$16 \mathrm{~b}, \mathrm{R}^{1}=\mathrm{CO}_{2} \mathrm{Et}(98 \%)$<smiles>[R]Cn1cccc1/C=C/C(C)=O</smiles>

8i, $R=$ vinyl $(96 \%)$

8j, R = alkynyl (94\%) 
Table 1: Preparation of 1,2-substituted pyrroles $8 \mathbf{a}-\mathbf{h} .^{a}$

\begin{tabular}{|c|c|c|c|c|c|c|c|}
\hline entry & 13 & 15 & $T\left({ }^{\circ} \mathrm{C}\right)$ & $t(\mathrm{~h})$ & $\mathrm{R}^{1}$ & $\operatorname{Ar}$ & $8(\%)^{b}$ \\
\hline 1 & $13 b$ & $15 b$ & 25 & 12 & $\mathrm{CO}_{2} \mathrm{Et}$ & $\mathrm{Ph}$ & $8 \mathbf{a}(98)$ \\
\hline 2 & $13 b$ & $15 c$ & 25 & 12 & $\mathrm{CN}$ & $\mathrm{Ph}$ & $8 b(99)^{c}$ \\
\hline 3 & $13 c$ & $15 a$ & 25 & 12 & $\mathrm{CO}_{2} \mathrm{Me}$ & $\mathrm{C}_{6} \mathrm{H}_{4}-2-\mathrm{Br}$ & $8 c(99)$ \\
\hline 4 & $13 c$ & $15 b$ & 25 & 12 & $\mathrm{CO}_{2} \mathrm{Et}$ & $\mathrm{C}_{6} \mathrm{H}_{4}-2-\mathrm{Br}$ & $8 d(93)$ \\
\hline 5 & $13 d$ & $15 b$ & 25 & 12 & $\mathrm{CO}_{2} \mathrm{Et}$ & $\mathrm{C}_{6} \mathrm{H}_{4}-3-\mathrm{OMe}$ & $8 e(90)$ \\
\hline 6 & $13 e$ & $15 a$ & 25 & 12 & $\mathrm{CO}_{2} \mathrm{Me}$ & $\mathrm{C}_{6} \mathrm{H}_{2}-2-\mathrm{Br}-4,5-(\mathrm{OMe})_{2}$ & $8 f(98)$ \\
\hline 7 & $13 c$ & d & 100 & 4 & COMe & $\mathrm{C}_{6} \mathrm{H}_{4}-2-\mathrm{Br}$ & $8 \mathrm{~g}(81)$ \\
\hline 8 & $13 e$ & $d$ & 100 & 4 & COMe & $\mathrm{C}_{6} \mathrm{H}_{2}-2-\mathrm{Br}-4,5-(\mathrm{OMe})_{2}$ & $8 h(72)$ \\
\hline
\end{tabular}

aReagents and conditions: 13 (1.0 mol equiv), 15 (1.2 mol equiv) and $\mathrm{NaH}$ ( $1.5 \mathrm{~mol}$ equiv). ${ }^{\mathrm{b}} \mathrm{After}$ purification by column chromatography. ${ }^{\mathrm{c}} \mathrm{As}$ an $E / Z$ $(95: 5)$ mixture. ${ }^{d}$ The reaction was carried out with acetone (1.3 mol equiv) and $\mathrm{KOH}(1.5 \mathrm{~mol}$ equiv) in $\mathrm{MeOH}$.

previous approach, starting from the treatment of 13a with $\mathbf{1 5 a}, \mathbf{b}$ to give 3-(pyrrol-2-yl)acrylates 16a-b (Scheme 2). The latter compounds were alkylated with allyl bromide (14e) and propargyl bromide (14f) to generate pyrroles $\mathbf{8 i}, \mathbf{j}$, respectively, in high yields.

The synthesis of octahydropyrrolo[3,4-e]indoles $\mathbf{9 / 1 0}$ was achieved through a Diels-Alder reaction between the 2-vinylpyrroles 8a-j and 16a,b and maleimides $7 \mathbf{a}-\mathbf{c}$ under thermal conditions (Scheme 3). N-Unsubstituted 2-vinylpyrroles $\mathbf{1 6 a}, \mathbf{b}$ were chosen as the dienes to evaluate the reactivity with diverse dienophiles. The reaction of acrolein, methyl acrylate, maleic anhydride and maleimide $\left(\mathrm{R}^{3}=\mathrm{H}, 7 \mathbf{a}\right)$ in xylene by heating up to $150{ }^{\circ} \mathrm{C}$ failed to provide the corresponding adducts. It was possible to recover the starting materials, which were accompanied by a decomposition residue. In contrast, maleimides $\mathbf{7 b}$ and $\mathbf{7 c}$ reacted efficiently to furnish the respective endo/exo adducts $\mathbf{9 a}-\mathbf{d} / \mathbf{1 0 a}-\mathbf{d}$ in good to high endo diastereoselectivity and yields (Table 2, entries 1-4). The cycloaddition with $\mathbf{7 c}$ led to the best selectivity (vide infra).

The structure of the endo and exo diastereoisomers was established by ROESY experiments. In the endo isomer $\mathbf{9 m}$, for example, the irradiation of the signal of proton $\mathrm{H}-4$ enhanced the signals of protons $\mathrm{H}-3 \mathrm{a}$ and $\mathrm{H}-8 \mathrm{~b}$, indicating that the three protons are on the same side. In the case of the exo isomer $10 \mathrm{~m}$, the irradiation of the singlet of the methyl group of the C-4 acetyl group increased the size of the signals of the protons $\mathrm{H}-3 \mathrm{a}$ and $\mathrm{H}-8 \mathrm{~b}$, which are located on the same side as the acetyl group. The unambiguous assignment of their structures was accomplished by a single-crystal X-ray diffraction crystallography of both endo $\mathbf{9 m}$ and exo $\mathbf{1 0 m}$ adducts (Figure 2) [43].

In addition, the thermal cycloadditions of 2-vinylpyrroles $\mathbf{8 a - j}$ and maleimides $\mathbf{7 b}, \mathbf{c}$ took place satisfactorily to deliver the expected adducts $9 \mathbf{e}-\mathbf{p} / \mathbf{1 0 e}-\mathbf{p}$, also with high endo diastereoselectivity and good yields (Table 2, entries 5-16). None of the series of mixtures $9 \mathbf{a}-\mathbf{p} / \mathbf{1 0 a}-\mathbf{p}$ corresponds to the direct products of the Diels-Alder cycloadditions, since they are derivatives resulting from the double bond isomerization of adducts 17 (i.e., migration from the pyrrole-fused exo cyclic position to the endo cyclic aromatic tetrahydroindole skeleton) [32]. Any attempt to isolate or detect $\mathbf{1 7}$ during the trials turned out to be unsuccessful [35]. It is noteworthy that there have been almost no reports to date on the uncommon highly diastereoselective Diels-Alder reactions of analogous 2-vinyl or 3-vinylpyrroles [32], nor on the reactivity of 2-vinylpyrroles substituted by electron-withdrawing groups [34,35].

Interestingly, all the 2-vinylpyrroles, including the $\mathrm{N}$-unsubstituted 16a,b or the $\mathrm{N}$-substituted ones $8 \mathbf{a}$ and $\mathbf{8 c}-\mathbf{j}$, furnished a high endo stereoselectivity with dienophile $7 \mathbf{c}$, except the

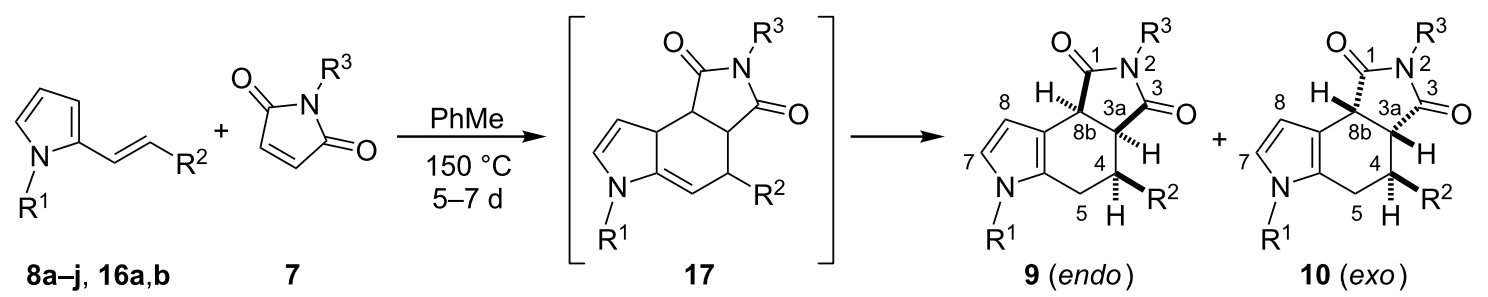


Table 2: Diels-Alder reactions of 2-vinylpyrroles $8 a-j$ and $16 a, b$ with maleimides $7 b, c{ }^{a}$

\begin{tabular}{|c|c|c|c|c|c|c|}
\hline entry & diene & 7 & $\mathrm{R}^{1}$ & $\mathrm{R}^{2}$ & $\mathrm{R}^{3}$ & 9/10 (ratio) ${ }^{\mathrm{b}}(\%)^{\mathrm{c}}$ \\
\hline 1 & $16 a$ & $7 b$ & $\mathrm{H}$ & $\mathrm{CO}_{2} \mathrm{Me}$ & $\mathrm{Me}$ & $9 \mathbf{a} / 10 \mathbf{a}(70: 30)(72)$ \\
\hline 2 & $16 b$ & $7 b$ & $\mathrm{H}$ & $\mathrm{CO}_{2} \mathrm{Et}$ & $\mathrm{Me}$ & 9b/10b (75:25) (74) \\
\hline 3 & $16 a$ & $7 c$ & $\mathrm{H}$ & $\mathrm{CO}_{2} \mathrm{Me}$ & $\mathrm{Ph}$ & $9 c / 10 c(94: 6)(73)$ \\
\hline 4 & $16 b$ & $7 c$ & $\mathrm{H}$ & $\mathrm{CO}_{2} \mathrm{Et}$ & $\mathrm{Ph}$ & 9d/10d $(97: 3)(71)^{d}$ \\
\hline 5 & $8 a$ & 7c & $\mathrm{Bn}$ & $\mathrm{CO}_{2} \mathrm{Et}$ & $\mathrm{Ph}$ & $9 e / 10 e(95: 5)(95)$ \\
\hline 6 & $8 b$ & 7c & $\mathrm{Bn}$ & $\mathrm{CN}$ & $\mathrm{Ph}$ & 9f/10f (76:24) (94) \\
\hline 7 & $8 c$ & $7 b$ & $\mathrm{CH}_{2} \mathrm{C}_{6} \mathrm{H}_{4}-2-\mathrm{Br}$ & $\mathrm{CO}_{2} \mathrm{Me}$ & $\mathrm{Me}$ & $9 \mathbf{g} / \mathbf{1 0 g}(99: 1)(94)^{d}$ \\
\hline 8 & $8 c$ & $7 c$ & $\mathrm{CH}_{2} \mathrm{C}_{6} \mathrm{H}_{4}-2-\mathrm{Br}$ & $\mathrm{CO}_{2} \mathrm{Me}$ & $\mathrm{Ph}$ & 9h/10h $(99: 1)(98)^{d}$ \\
\hline 9 & $8 d$ & $7 b$ & $\mathrm{CH}_{2} \mathrm{C}_{6} \mathrm{H}_{4}-2-\mathrm{Br}$ & $\mathrm{CO}_{2} \mathrm{Et}$ & $\mathrm{Me}$ & $9 \mathbf{9} / 10 \mathbf{i}(99: 1)(97)^{d}$ \\
\hline 10 & $8 d$ & $7 c$ & $\mathrm{CH}_{2} \mathrm{C}_{6} \mathrm{H}_{4}-2-\mathrm{Br}$ & $\mathrm{CO}_{2} \mathrm{Et}$ & $\mathrm{Ph}$ & $\mathbf{9 j} / \mathbf{1 0 j}(97: 3)(96)$ \\
\hline 11 & $8 e$ & $7 c$ & $\mathrm{CH}_{2} \mathrm{C}_{6} \mathrm{H}_{4}-3-\mathrm{OMe}$ & $\mathrm{CO}_{2} \mathrm{Et}$ & $\mathrm{Ph}$ & 9k/10k (98:2) (97) \\
\hline 12 & $8 f$ & 7c & $\mathrm{CH}_{2} \mathrm{C}_{6} \mathrm{H}_{2}-2-\mathrm{Br}-4,5-(\mathrm{OMe})_{2}$ & $\mathrm{CO}_{2} \mathrm{Me}$ & $\mathrm{Ph}$ & 9I/10l (93:7) (95) \\
\hline 13 & $8 g$ & $7 c$ & $\mathrm{CH}_{2} \mathrm{C}_{6} \mathrm{H}_{4}-2-\mathrm{Br}$ & COMe & $\mathrm{Ph}$ & 9m/10m (91:9) (94) \\
\hline 14 & $8 h$ & $7 c$ & $\mathrm{CH}_{2} \mathrm{C}_{6} \mathrm{H}_{2}-2-\mathrm{Br}-4,5-(\mathrm{OMe})_{2}$ & COMe & $\mathrm{Ph}$ & $9 n / 10 n(90: 10)(93)$ \\
\hline 15 & $8 \mathbf{i}$ & 7c & allyl & $\mathrm{CO}_{2} \mathrm{Me}$ & $\mathrm{Ph}$ & 9o/10o $(98: 2)(92)^{d}$ \\
\hline 16 & 8j & 7c & propargyl & $\mathrm{CO}_{2} \mathrm{Me}$ & $\mathrm{Ph}$ & $9 p / 10 p(99: 1)(95)^{d}$ \\
\hline
\end{tabular}

aReagents: 8 and $\mathbf{1 6}$ (1.0 mol equiv) and $\mathbf{7}$ (1.2 mol equiv). ${ }^{\mathrm{b}}$ Calculated by ${ }^{1} \mathrm{H}$ NMR from the crude reaction mixtures. ${ }^{\mathrm{C}}$ After purification by column chromatography and as the addition of the yields of both isomers. ${ }^{d}$ Following purification by column chromatography and as the yield of the major isomer.

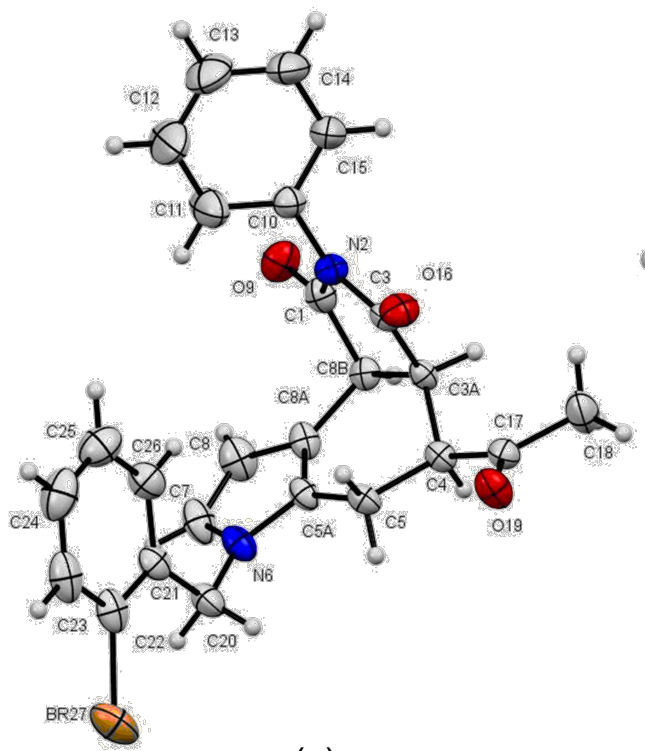

(a)

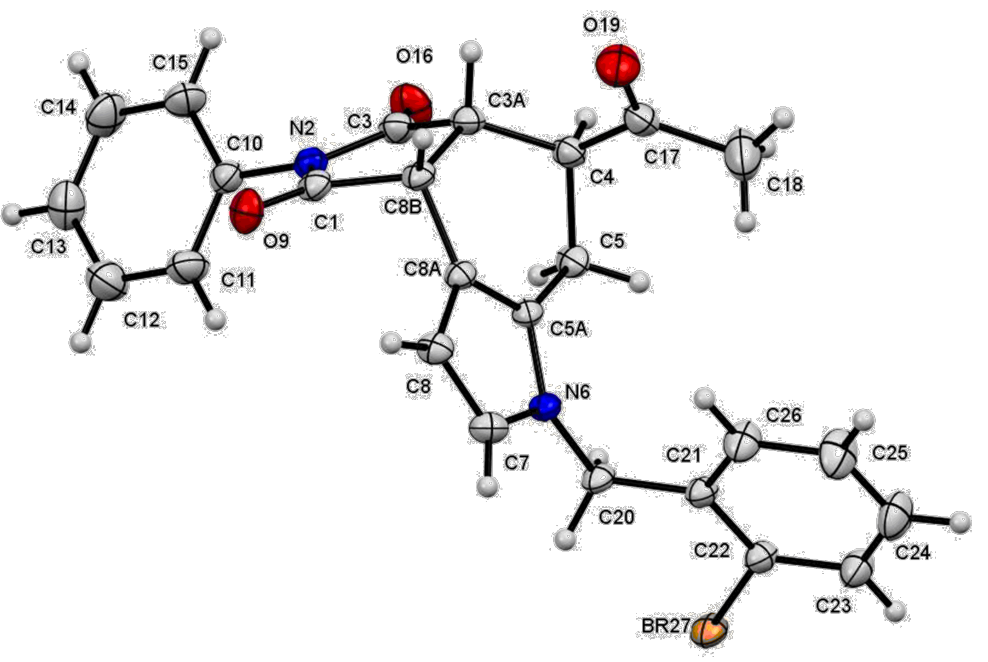

(b)

Figure 2: Structures of $9 \mathrm{~m}(\mathrm{a})$ and $\mathbf{1 0 m}$ (b) as determined by single-crystal X-ray diffraction crystallography (ellipsoids at the $30 \%$ probability level).

$N$-substituted 2-acrylonitrile pyrrole $\mathbf{8 b}$. Accordingly, the $\mathrm{R}^{2}$ substituent in the diene would play an important role in directing the endo/exo orientation of the approach to the maleimide at the transition state (TS). Therefore, the endo diastereoselectivity is apparently not controlled by the presence or the absence of the substituent bonded to the nitrogen atom of the heterocycle. Since it is not clear what factors favor this relevant selectivity, the geometry and energy of the TSs were calculated for some of the diene-dienophile pairs depicted in Table 2 (vide infra). 


\section{Cyclization via an intramolecular Heck arylation reaction}

Before attempting the intramolecular Heck cross-coupling reaction of the octahydroindoles $\mathbf{9 / 1 0}$ to the pentacycles $\mathbf{1 1}$, the process was explored with the simple substrates $\mathbf{8 c}, \mathbf{d}$ and $\mathbf{8 g}$ (Scheme 4). Thus, the $\operatorname{Pd}(0)$-catalyzed cyclization of the latter vinylpyrroles with potassium acetate and using acetonitrile or dimethylacetamide (DMA) as the solvent at $100{ }^{\circ} \mathrm{C}$ afforded pyrrolo[2,1-a]isoindoles 18a-c in good yields. This annulation process was regioselective, showing a preference of the crosscoupling reaction with the $\mathrm{C}-5$ pyrrolic position and not with the vinyl moiety, which would give the dihydropyrrolo[1,2$b$ ]isoquinoline 19. A similar chemoselectivity has been previously observed, being explained as a consequence of the acidity of the $\mathrm{C}-\mathrm{H}$ bond being cleaved $[6,44]$.

Additional intramolecular cross-coupling reactions were carried out by utilizing dimethyl malonates $\mathbf{8 k}$ and $\mathbf{8 1}$, which were prepared through the N-benzylation of $\mathbf{1 6} \mathbf{c}$ with benzyl bromides 14b and 14d, respectively (Scheme 5). Pyrrole 16c was synthesized by Knoevenagel reaction of 13a with dimethyl malonate [42]. The $\operatorname{Pd}(0)$-catalyzed cyclization of $\mathbf{8 k}$ and $\mathbf{8 1}$ required a temperature of $140{ }^{\circ} \mathrm{C}$, but provided pyrrolo[2,1-a]isoindoles $\mathbf{1 8 d}$ and $\mathbf{1 8 e}$, respectively, in good yields.

Once having the optimal reaction conditions for the palladium(0)-catalyzed cross-coupling reaction leading to the cyclization of $N$-(2-bromobenzyl)pyrroles $\mathbf{8}$, the endo-octahydropyrrolo[3,4-e]indole-1,3-diones $\mathbf{9 g}-\mathbf{j}$ and $\mathbf{9 m}$ were con- verted into pentacycles 11a-e through the same methodology (Table 3). Optimized reaction conditions were established by using $\mathbf{9 j}$ as the model substrate and changing the catalyst, base and solvent. Palladium acetate was not efficient for the conversion, even though the base was modified (Table 3, entries 1 and 2). $\mathrm{Pd}\left(\mathrm{PPh}_{3}\right)_{4}$ was a better catalyst when employing potassium acetate as the base, and $\mathrm{MeCN}$ was more efficient than DMF, affording 11a in a better yield (Table 3, entries 3 and 4). The cyclization of $\mathbf{9 g - i}$ and $\mathbf{9 m}$ was performed under similar conditions, with $\mathrm{MeCN}$ as the solvent, to produce the aza-pentacycles 11b-e, respectively, in modest to good yields (Table 3, entries 5-8).

An alternative approach for the synthesis of pentacycles $\mathbf{1 1}$ would be the Diels-Alder cycloaddition of pyrrolo[2,1- $a$ ]isoindoles 18 with maleimides $\mathbf{7}$. Indeed, the reaction between $\mathbf{1 8 a}$ and $7 \mathrm{c}$ successfully proceeded to give a diastereoisomeric mixture of adducts $\mathbf{1 1 b} / \mathbf{2 0}$ (91:9) in high yield (Scheme 6). Although the reactivity was much lower (10 days) compared to the cycloadditions with 2-vinylpyrroles $\mathbf{8 a - h}$ (7 days) (Table 2), the diastereoselectivity remained rather high and similar to derivatives $\mathbf{8 g}$ and $\mathbf{8 h}$.

Considering the significant biological activity of indoles, octahydropyrrolo[3,4-e]indole-1,3-diones 9 were submitted to aromatization to generate the corresponding tetrahydropyrrolo[3,4-e ]indole-1,3-diones 21 (Table 4). When 9e was treated with manganese oxide [32] at 25 or $100{ }^{\circ} \mathrm{C}$ for $24 \mathrm{~h}$, no reaction occurred and the starting material was recovered (Table 4 ,

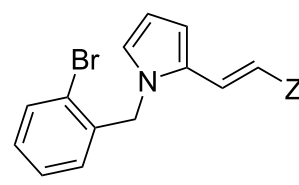

$8 \mathrm{c}, \mathrm{Z}=\mathrm{CO}_{2} \mathrm{Me}$

$8 d, Z=\mathrm{CO}_{2} \mathrm{Et}$

$8 \mathrm{~g}, \mathrm{Z}=\mathrm{COMe}$

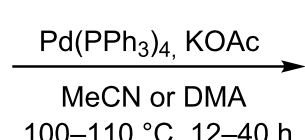
$100-110^{\circ} \mathrm{C}, 12-40 \mathrm{~h}$<smiles>[Z]C=Cc1ccc2n1Cc1ccccc1-2</smiles>

18a, $\mathrm{Z}=\mathrm{CO}_{2} \mathrm{Me}(88 \%)$

$18 \mathrm{~b}, \mathrm{Z}=\mathrm{CO}_{2} \mathrm{Et}(83 \%)$

18c, $Z=$ COMe $(74 \%)$<smiles>[Z]C=C1c2ccccc2Cn2cccc21</smiles>

19

Scheme 4: $\operatorname{Pd}(0)$-catalyzed intramolecular Heck cross-coupling reaction of 2-vinylpyrroles $\mathbf{8 c}, \mathbf{d}$ and $\mathbf{8 g}$.

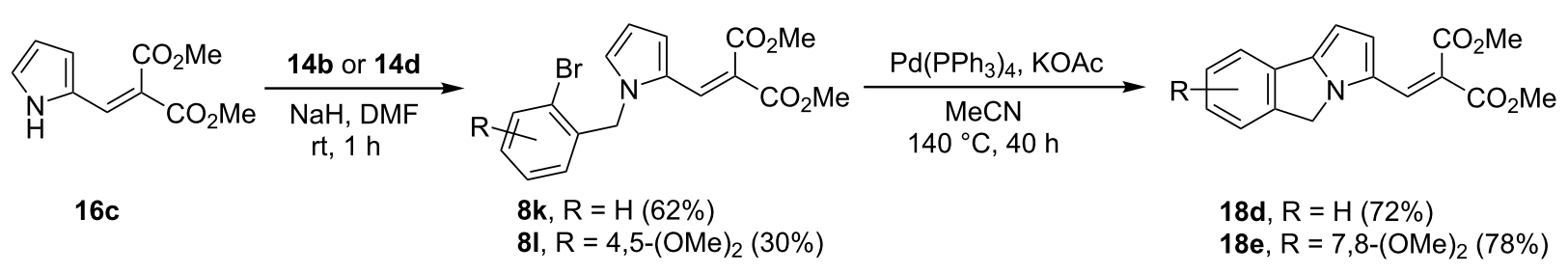


Table 3: Heck cross-coupling reactions of $\mathbf{9 g}-\mathbf{j}$ and $9 \mathrm{~m}$ for the preparation of pentacycles $11 \mathrm{a}-\mathbf{e} \mathrm{.}^{\mathrm{a}}$

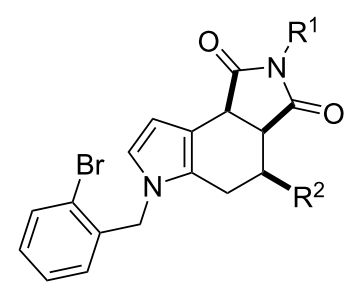

9

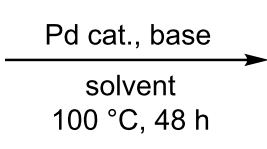

$100^{\circ} \mathrm{C}, 48 \mathrm{~h}$<smiles>[R]C1Cc2c(cc3n2Cc2ccccc2-3)C2C(=O)N([R])C(=O)C12</smiles>

11

\begin{tabular}{|c|c|c|c|c|c|c|c|}
\hline entry & 9 & $\mathrm{R}^{1}$ & $\mathrm{R}^{2}$ & catalyst & base & solvent & $11(\%)^{b}$ \\
\hline 1 & $9 j$ & $\mathrm{Ph}$ & $\mathrm{CO}_{2} \mathrm{Et}$ & $\mathrm{Pd}(\mathrm{OAc})_{2}$ & $\mathrm{~K}_{2} \mathrm{CO}_{3}$ & DMF & c \\
\hline 2 & 9j & $\mathrm{Ph}$ & $\mathrm{CO}_{2} \mathrm{Et}$ & $\mathrm{Pd}(\mathrm{OAc})_{2}$ & $\mathrm{Cs}_{2} \mathrm{CO}_{3}$ & DMF & c \\
\hline 3 & 9j & $\mathrm{Ph}$ & $\mathrm{CO}_{2} \mathrm{Et}$ & $\mathrm{Pd}\left(\mathrm{PPh}_{3}\right)_{4}$ & KOAc & DMF & $11 a(53)$ \\
\hline 4 & $9 j$ & $\mathrm{Ph}$ & $\mathrm{CO}_{2} \mathrm{Et}$ & $\mathrm{Pd}\left(\mathrm{PPh}_{3}\right)_{4}$ & KOAC & $\mathrm{MeCN}$ & $11 \mathbf{a}(75)$ \\
\hline 5 & $9 h$ & $\mathrm{Ph}$ & $\mathrm{CO}_{2} \mathrm{Me}$ & $\mathrm{Pd}\left(\mathrm{PPh}_{3}\right)_{4}$ & KOAC & MeCN & 11b (77) \\
\hline 6 & $9 \mathrm{i}$ & $\mathrm{Me}$ & $\mathrm{CO}_{2} \mathrm{Et}$ & $\mathrm{Pd}\left(\mathrm{PPh}_{3}\right)_{4}$ & KOAC & MeCN & $11 c(81)$ \\
\hline 7 & $9 m$ & $\mathrm{Ph}$ & COMe & $\mathrm{Pd}\left(\mathrm{PPh}_{3}\right)_{4}$ & KOAC & $\mathrm{MeCN}$ & $11 d(48)$ \\
\hline 8 & $9 \mathrm{~g}$ & $\mathrm{Me}$ & $\mathrm{CO}_{2} \mathrm{Me}$ & $\mathrm{Pd}\left(\mathrm{PPh}_{3}\right)_{4}$ & KOAC & MeCN & $11 e(86)$ \\
\hline
\end{tabular}

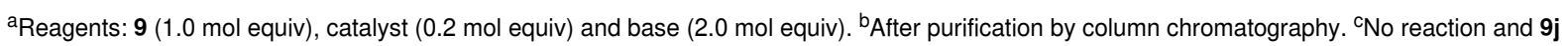
was recovered.

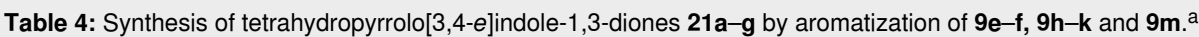

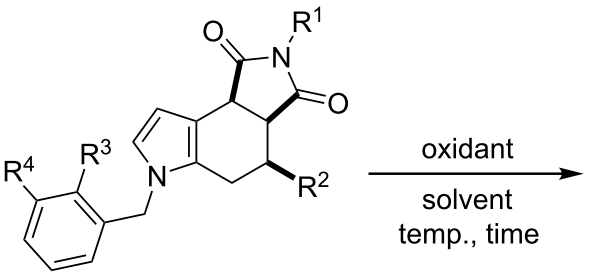

9<smiles></smiles>

21

\begin{tabular}{|c|c|c|c|c|c|c|c|c|c|c|}
\hline entry & 9 & $\mathrm{R}^{1}$ & $\mathrm{R}^{2}$ & $\mathrm{R}^{3}$ & $\mathrm{R}^{4}$ & oxidant & solvent & $T\left({ }^{\circ} \mathrm{C}\right)$ & $t(\mathrm{~h})$ & $21(\%)^{b}$ \\
\hline 1 & $9 e$ & $\mathrm{Ph}$ & $\mathrm{CO}_{2} \mathrm{Et}$ & $\mathrm{H}$ & $\mathrm{H}$ & $\mathrm{MnO}_{2}$ & $\mathrm{CH}_{2} \mathrm{Cl}_{2}$ & 25 & 24 & (c) \\
\hline 2 & $9 e$ & $\mathrm{Ph}$ & $\mathrm{CO}_{2} \mathrm{Et}$ & $\mathrm{H}$ & $\mathrm{H}$ & $\mathrm{MnO}_{2}$ & PhMe & 100 & 24 & (c) \\
\hline 3 & $9 e$ & $\mathrm{Ph}$ & $\mathrm{CO}_{2} \mathrm{Et}$ & $\mathrm{H}$ & $\mathrm{H}$ & $\mathrm{DDQ}$ & $\mathrm{CH}_{2} \mathrm{Cl}_{2}$ & 25 & 48 & 21a (88) \\
\hline 4 & $9 f$ & $\mathrm{Ph}$ & $\mathrm{CN}$ & $\mathrm{H}$ & $\mathrm{H}$ & $\mathrm{DDQ}$ & $\mathrm{CH}_{2} \mathrm{Cl}_{2}$ & 25 & 48 & 21b (94) \\
\hline 5 & $9 \mathrm{~h}$ & $\mathrm{Ph}$ & $\mathrm{CO}_{2} \mathrm{Me}$ & $\mathrm{Br}$ & $\mathrm{H}$ & $\mathrm{MnO}_{2}$ & PhMe & 140 & 24 & 21c (69) \\
\hline 6 & $9 \mathrm{~h}$ & $\mathrm{Ph}$ & $\mathrm{CO}_{2} \mathrm{Me}$ & $\mathrm{Br}$ & $\mathrm{H}$ & $\mathrm{DDQ}$ & $\mathrm{CH}_{2} \mathrm{Cl}_{2}$ & 25 & 48 & 21c (90) \\
\hline 7 & $9 i$ & $\mathrm{Me}$ & $\mathrm{CO}_{2} \mathrm{Et}$ & $\mathrm{Br}$ & $\mathrm{H}$ & $\mathrm{DDQ}$ & $\mathrm{CH}_{2} \mathrm{Cl}_{2}$ & 25 & 48 & 21d (86) \\
\hline 8 & $9 j$ & $\mathrm{Ph}$ & $\mathrm{CO}_{2} \mathrm{Et}$ & $\mathrm{Br}$ & $\mathrm{H}$ & DDQ & $\mathrm{CH}_{2} \mathrm{Cl}_{2}$ & 25 & 48 & 21e (89) \\
\hline 9 & $9 k$ & $\mathrm{Ph}$ & $\mathrm{CO}_{2} \mathrm{Et}$ & $\mathrm{H}$ & OMe & DDQ & $\mathrm{CH}_{2} \mathrm{Cl}_{2}$ & 25 & 48 & $21 f(90)$ \\
\hline 10 & $9 m$ & $\mathrm{Ph}$ & COMe & $\mathrm{Br}$ & $\mathrm{H}$ & DDQ & $\mathrm{CH}_{2} \mathrm{Cl}_{2}$ & 25 & 48 & $21 \mathrm{~g}(90)$ \\
\hline
\end{tabular}

aReagents: 9 (1.0 mol equiv), $\mathrm{MnO}_{2}$ (4.0 mol equiv) and DDQ (2.5 mol equiv). ${ }^{b}$ Following purification by column chromatography. ${ }^{\mathrm{c}} \mathrm{Substrate} 9 \mathrm{e}$ was recovered. 


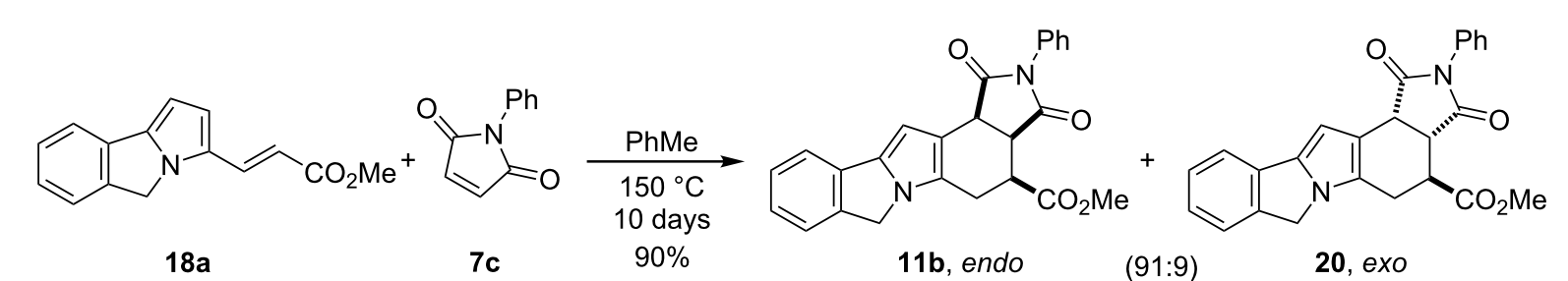

Scheme 6: Diastereoselective Diels-Alder reaction of pyrrolo[2,1-a]isoindole 18a with 7c.

entries 1 and 2). However, the use of 2,3-dichloro-5,6-dicyano1,4-benzoquinone (DDQ) at $25{ }^{\circ} \mathrm{C}$ for $48 \mathrm{~h}$ led to the aromatized compound 21 a in high yield (Table 4 , entry 3 ). Under similar reaction conditions, the series of pyrrolo[3,4-e]indole-1,3diones $\mathbf{2 1 b}-\mathbf{g}$ was resulted in high yields (Table 4 , entries 4 and 6-10). Derivative 21c was also prepared by the oxidation of $\mathbf{9 h}$ with manganese oxide at higher temperature, but the yield was lower (Table 4, entry 5).

As part of our interest in further functionalizing octahydropyrrolo[3,4-e ]indole-1,3-diones 9 , formylation was herein investigated under usual Vilsmeier-Haack reaction conditions (Table 5). Fortunately, the series of 7-formyl derivatives 22a-e was attained in good yields. This synthetic approach allows for the preparation of widely polysubstituted octahydropyrrolo[3,4$e$ ]indole-1,3-dione derivatives. However, the conversion into their aromatic skeleton either by using manganese oxide or DDQ as the oxidizing reagents, or even including $\mathrm{Pd} / \mathrm{C}$ at high temperatures $\left(250^{\circ} \mathrm{C}\right)$ [45], failed to obtain the series of indoles 23. It is likely that the electron withdrawing effect of the formyl group at the $\mathrm{C}-7$ position counterbalance the delocalization direction of the electronic density provided by the nitrogen lone-pair, which plausibly stabilizes the cationic or radical species formed by the oxidant reagent during the aromatization process [46], as efficiently occurred with derivatives 9.

Finally, in order to obtain the aromatic indole-based pentacycles 12, the aromatization of pentacycles 11 was explored. Although the use of DDQ under the oxidative reaction conditions shown in Table 4 was efficient for the preparation of derivatives 21, the conversion of $\mathbf{1 1 a}$ into $\mathbf{1 2}$ was unsuccessful (Scheme 7). The action of active $\mathrm{MnO}_{2}$ in toluene at high temperature was able to promote the aromatization of 11a affording pentacycle 12, in low yield (30\%) [47]. Moreover, when the oxidation was carried out in methylene chloride, pentacycle $\mathbf{1 2}$ was delivered in a higher yield (71\%). The synthesis of analogs to the latter compound has attracted much attention in recent years [21].

\section{Theoretical calculations}

The Diels-Alder reaction of vinylpyrroles $\mathbf{8 b}, \mathbf{8 c}$ and $\mathbf{8 g}$ with maleimides $\mathbf{7 b}$ and $\mathbf{7 c}$ resulted in a highly diastereoselective cycloaddition leading to the mixture of endo/exo cycloadducts 9/10, where the endo product 9 was the major one (Scheme 3

Table 5: Preparation of derivatives $22 a-e$ by formylation of octahydropyrrolo[3,4-e]indole-1,3-diones $9 .^{\text {a }}$

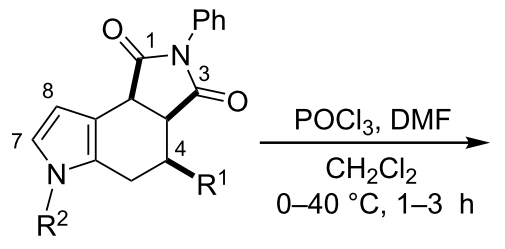

9<smiles>[R]C1Cc2c(cc(C)n2[R])C2C(=O)N(c3ccccc3)C(=O)C12</smiles>

22<smiles>[R]c1cc2c(cc1C)C(=O)N(c1ccccc1)C2=O</smiles>

23

\begin{tabular}{llllcll}
\hline entry & 9 & $\mathrm{R}^{1}$ & $\mathrm{R}^{2}$ & $T\left({ }^{\circ} \mathrm{C}\right)$ & $t(\mathrm{~h})$ & $\mathbf{2 2}(\%)^{\mathrm{b}}$ \\
\hline 1 & $9 \mathbf{9 f}$ & $\mathrm{CN}$ & $\mathrm{Bn}$ & 40 & 1 & $\mathbf{2 2 a}(95)$ \\
2 & $9 \mathbf{h}$ & $\mathrm{CO}_{2} \mathrm{Me}$ & $\mathrm{CH}_{2} \mathrm{C}_{6} \mathrm{H}_{4}-2-\mathrm{Br}$ & 0 & 3 & $\mathbf{2 2 b}(88)$ \\
3 & $9 \mathbf{l}$ & $\mathrm{CO}_{2} \mathrm{Me}$ & $\mathrm{CH}_{2} \mathrm{C}_{6} \mathrm{H}_{2}-2-\mathrm{Br}-4,5-(\mathrm{OMe})_{2}$ & 0 & 2 & $\mathbf{2 2 c}(89)$ \\
4 & $9 \mathbf{0}$ & $\mathrm{CO}_{2} \mathrm{Me}$ & allyl & 25 & 2 & $\mathbf{2 2 d}(84)$ \\
5 & $9 \mathbf{p}$ & $\mathrm{CO}_{2} \mathrm{Me}$ & propargyl & 25 & 2 & $\mathbf{2 2 e}(80)$ \\
\hline
\end{tabular}

aReagents: 9 (1.0 mol equiv), $\mathrm{POCl}_{3}\left(1.2\right.$ mol equiv) and DMF (1.2 mol equiv). ${ }^{b}$ After purification by column chromatography. 
<smiles>CCOC(=O)C1Cc2c(cc3n2Cc2ccccc2-3)C2C(=O)N(c3ccccc3)C(=O)C12</smiles>

$11 \mathrm{a}$

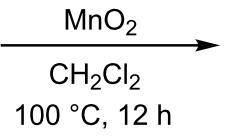

$100{ }^{\circ} \mathrm{C}, 12 \mathrm{~h}$<smiles></smiles>

$12(71 \%)$

Scheme 7: Synthetic approach to the fused aza-heterocyclic pentacycle 12.

and Table 2). Considering the synthetic and biological potential value of the resulting products in the construction of a series of pyrrolo- and isoindolo-fused polycyclic indoles and octahydroindoles, a quantum theoretical study of the TSs was conducted to gain insight into the main factors that control this endo diastereoselectivity.

Firstly, the geometry and energy of the TSs and the associated minima along the reaction coordinates of the $\mathrm{N}$-substituted diene $\mathbf{8 g}$ with maleimide $\mathbf{7 c}$ were calculated at the M06-2X/6$31+\mathrm{G}(\mathrm{d}, \mathrm{p})$ level of theory [48-51] on the Gaussian 09 program [52]. For each stationary point of the Diels-Alder cycloadditions, the relative energy is summarized in Table 6 and the geometry is displayed in Figure 3. The data indicate a single concerted TS not only for the cycloaddition of $8 \mathbf{g} / \mathbf{7} \mathbf{c}$, but also for all the endo and exo processes (Supporting Information
File 1, Appendix 5). The Gibbs energy was also calculated for each reaction and in most cases showed a good correlation with the ZPE-corrected energy (Table 6). All the endo approaches were lower in energy than the exo approaches, reaching the TSs from the supramolecular complexes (SCs) [53]. For most of the cycloadditions, the difference in energy of the TSs were large enough ( $>3 \mathrm{kcal} / \mathrm{mol}$ ) to find an endo/exo diastereoisomeric ratio greater than 99:1, which is in agreement with the observed experimental results.

For the reaction with $\mathbf{8 b}\left(\mathrm{R}^{2}=\mathrm{CN}\right)$ the calculated endo/exo ratio (99.4:0.6) and the experimental one (76:24) did not concur. However, the ratio determined through the Gibbs energy (endo/exo, 79.9:20.1) matched better. Actually, the reactivity of diene $\mathbf{8 b}$ would be expected to be lower due to a greater deactivation of the cyano group, as suggested by

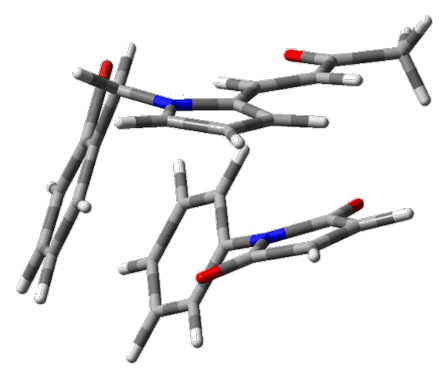

(a)

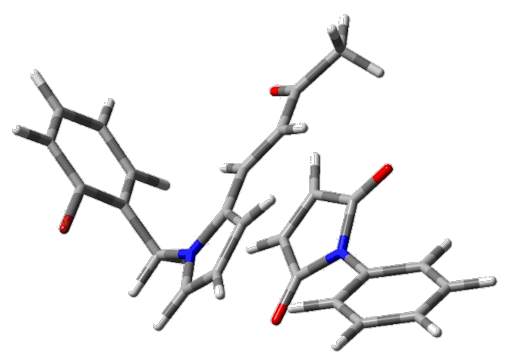

(d)

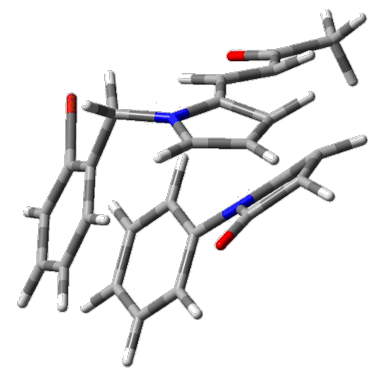

(b)

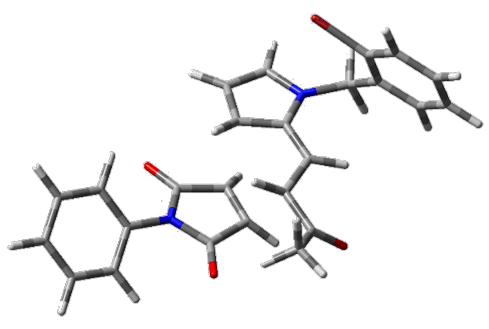

(e)

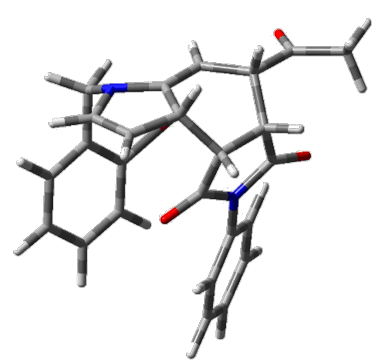

(c)

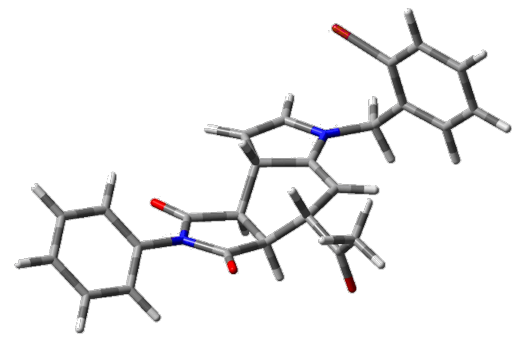

(f)

Figure 3: M06-2X/6-31+G(d,p) Optimized geometry for each of the SCs (a and d), TSs (b and e) and ADs (c and f) of the Diels-Alder reactions of diene $\mathbf{8 g}$ and dienophile $7 \mathrm{c}$, for the endo $(\mathrm{a}-\mathrm{c})$ and the exo $(\mathrm{d}-\mathrm{f})$ approaches, respectively. 
Table 6: Calculated [M06-2X/6-31+G(d,p)] relative ZPE-corrected energy (kcal/mol) of the supramolecular complexes (SCs), TSs and adducts (ADs) located on the potential surfaces for the Diels-Alder reactions of the dienes $\mathbf{8 b}, \mathbf{8 c}, \mathbf{8 g}, \mathbf{8 j}, \mathbf{1 6} \mathbf{a}$ and $\mathbf{1 8 a}$, and dienophiles $\mathbf{7 b}, \mathbf{c}$. $^{\mathrm{a}}$

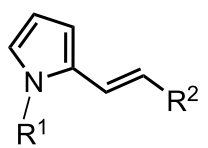

8b, $R^{1}=B n, R^{2}=C N$

8c, $\mathrm{R}^{1}=\mathrm{CH}_{2} \mathrm{C}_{6} \mathrm{H}_{4}-2-\mathrm{Br}, \mathrm{R}^{2}=\mathrm{CO}_{2} \mathrm{Me}$

8g, $\mathrm{R}^{1}=\mathrm{CH}_{2} \mathrm{C}_{6} \mathrm{H}_{4}-2-\mathrm{Br}, \mathrm{R}^{2}=\mathrm{COMe}$

8j, $\mathrm{R}^{1}=\mathrm{CH}_{2} \mathrm{CCH}, \mathrm{R}^{2}=\mathrm{CO}_{2} \mathrm{Me}$

16a, $R^{1}=\mathrm{H}, \mathrm{R}^{2}=\mathrm{CO}_{2} \mathrm{Me}$

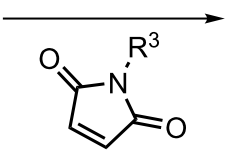

7b, $R^{3}=M e$

$7 c, R^{3}=P h$<smiles>[R]C1Cc2c(ccn2[R1])[C@@H]2C(=O)N([R])C(=O)[C@H]12</smiles>

9 (endo)

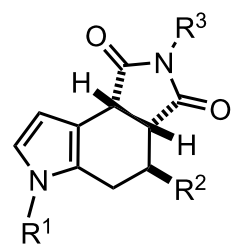

$10(e x o)$

\begin{tabular}{|c|c|c|c|c|c|}
\hline cycloaddends & $\mathrm{SC}^{\mathrm{b}}$ & $\mathrm{TS}^{\mathrm{b}}$ & $A D^{b}$ & $\operatorname{diff}^{c}$ & $9 / 10$ or $11 b / 20(\%)^{d}(\%)^{e}(\%)^{f}$ \\
\hline $8 \mathrm{~b} / 7 \mathrm{c}-$ endo & $0.00(0.00)$ & $26.92(29.72)$ & $-9.76(-6.47)$ & $0.00(0.00)$ & $9 f(99.4)(79.9)(76)$ \\
\hline $8 b / 7 c-e x o$ & $0.76(0.65)$ & $29.99(30.53)$ & $-7.94(-7.31)$ & $3.07(0.82)$ & $10 f(0.6)(20.1)(24)$ \\
\hline 8c/7b-endo & $0.00(0.00)$ & $24.10(26.21)$ & $-12.99(-10.79)$ & $0.00(0.00)$ & $9 \mathbf{g}(99.9)(88.8)(99)$ \\
\hline $8 c / 7 b-e x o$ & $2.96(0.94)$ & $28.32(27.44)$ & $-10.44(-11.12)$ & $4.22(1.23)$ & $\log (0.1)(11.2)(1)$ \\
\hline $8 \mathbf{c} / 7 \mathbf{c}-e n d o$ & $0.00(0.00)$ & $23.97(26.20)$ & $-10.31(-7.66)$ & $0.00(0.00)$ & 9h (100) (99.9) (99) \\
\hline $8 c / 7 c-e x o$ & $5.40(3.80)$ & $32.39(31.58)$ & $-5.38(-6.62)$ & $8.42(5.40)$ & $10 \mathrm{~h}(0)(0.01)(1)$ \\
\hline $8 \mathrm{~g} / 7 \mathbf{c}$-endo & $0.00(0.00)$ & $24.50(26.83)$ & $-9.60(-6.55)$ & $0.00(0.00)$ & $9 m(100)(99.9)(91)$ \\
\hline $8 \mathrm{~g} / 7 \mathrm{c}-\mathrm{exo}$ & $4.25(2.25)$ & $30.93(30.81)$ & $-6.41(-6.98)$ & $6.43(3.98)$ & $10 \mathrm{~m}(0)(0.1)(9)$ \\
\hline 8j/7c-endo & $0.00(0.00)$ & $23.18(25.49)$ & $-11.22(-9.62)$ & $0.00(0.00)$ & $9 p(99: 9)(99.6)(99)$ \\
\hline $8 \mathbf{j} / 7 \mathrm{c}-\mathrm{exo}$ & $3.11(0.58)$ & $28.96(28.82)$ & $-9.02(-9.28)$ & $5.77(3.33)$ & $10 p(0.1)(0.4)(1)$ \\
\hline 16a/7c-endo & $0.00(0.00)$ & $25.10(26.70)$ & $-7.72(-6.22)$ & $0.00(0.00)$ & 9c (100) (99.9) (94) \\
\hline $16 \mathrm{a} / 7 \mathrm{c}-\mathrm{exo}$ & $3.70(1.95)$ & $30.31(31.05)$ & $-6.90(-6.22)$ & $5.21(4.35)$ & $10 \mathrm{c}(0)(0.1)(6)$ \\
\hline 18a/7c-endo & $0.00(0.00)$ & $24.42(26.68)$ & $-6.25(-5.24)$ & $0.00(0.00)$ & 11b (100) (100) $(91)^{\mathrm{g}}$ \\
\hline $18 \mathrm{a} / 7 \mathrm{c}-\mathrm{exo}$ & $2.40(2.07)$ & $34.14(34.34)$ & $-4.39(-4.11)$ & $9.72(7.66)$ & $20(0)(0)(9)^{g}$ \\
\hline
\end{tabular}

aThe endo /exo TSs for each pair of cycloaddends lead to a mixture of adducts $\mathbf{9} / \mathbf{1 0}$ or $\mathbf{1 1 b} / \mathbf{2 0}$, whose ratios are indicated in both rows of the pairs $\mathbf{8} / \mathbf{7}$,

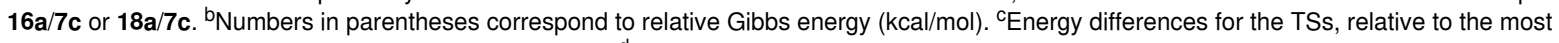

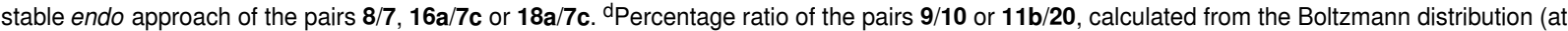

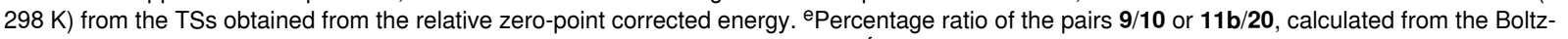
mann distribution (at $298 \mathrm{~K}$ ) of the TSs obtained from the relative Gibbs energies. 'Percentage ratio of the pairs $\mathbf{9} / \mathbf{1 0}$ or $\mathbf{1 1 b} / \mathbf{2 0}$, determined from the experimental Diels-Alder cycloadditions (Table 2). ${ }^{9}$ For the ratio of $\mathbf{1 1} \mathbf{b} / \mathbf{2 0}$, see Scheme 6.

comparing the most stable HOMO of this diene with the values for dienes 8c and $\mathbf{8 g}$ (Supporting Information File 1, Table S1). Hence, the latter dienes should be more reactive than diene $\mathbf{8 b}$, and consequently more stereoselective [54-56].

In contrast, the Gibbs energy for the diene/dienophile $\mathbf{8 c} / \mathbf{7 b}$ (88.8:11.2) did not completely match the experimental endo/exo (99:1) ratio, but the ZPE ratio (99.9:0.1) was in good agreement. For the cycloaddition of the pyrrolo[2,1- $a$ ]isoindole 18a with $\mathbf{7 c}$, there was an additional conjugated system involved capable of perturbing the electronic density of the diene. If one assumes that the nitrogen lone-pair was partially delocalized to the benzene ring, a decrease in the electronic density should be anticipated for the methyl acrylate dienic moiety. According to the perturbation theory [57], such an effect would cause a reduction in the cycloaddition reactivity, because the diene needs electron-donating substituents to enhance it (under normal electron demand). Indeed, under the same reaction conditions as those employed for dienes $\mathbf{8}$, it took 10 days of heating for diene 18a to be consumed (Scheme 6). Thus, the limited reactivity of this diene resulted in a lower diastereoselectivity than most of the other dienes $\mathbf{8}$ as well as $\mathbf{1 6} \mathbf{a}$.

Non-covalent intermolecular interactions (NCIs) between aromatic rings $(\pi \cdots \pi)[58,59]$ and alkyl and aromatic ring $\left(\mathrm{Csp}^{3}-\mathrm{H}\right) \cdots \pi$ stackings [59-62] are widely recognized, from both the experimental and theoretical viewpoint, as a major factor governing the conformational equilibrium, supramolecular assembly and stereoselective approaches of substrates and reagents or catalysts in a variety of processes. Examples include the substrate-enzyme recognition (the host-guest interaction) responsible for inducing pharmacological activity, the DNA- 
intercalation capable of generating biomolecular activity, molecular dynamics [63-70], and pericyclic reactions (Diels-Alder and 1,3-dipolar cycloadditions) [71-75].

To account for the endo selectivity of all the tested dienes, the geometry of cycloaddends at the TSs was carefully analyzed (Figure 4 and Supporting Information File 1, Appendix 6) to determine the effects, such as NCIs, that occur to stabilize it. For example, in the endo TS of the cycloaddition of $8 \mathrm{~g} / 7 \mathbf{c}$, the benzene rings of both reagents closely approach each other in an observable $\pi \cdots \pi$ offset stacked interaction (3.683 $\AA)(\pi \cdots \sigma$ attraction) (Figure $4 \mathrm{c}$ and Table 7), which is more stable than the eclipsed face-to-face geometry, overcoming the $\pi \cdots \pi$ repulsions $[58,59]$. The same interaction is also noticed for the SC (Figure 3a). Of course, this interaction is not present at the exo TS (Figure 3e). Similar interactions are perceptible in the approaches of cycloaddends $8 \mathbf{b} / 7 \mathbf{c}$ and $\mathbf{8 c} / \mathbf{7 c}$ (Figure $4 a, b$ and Supporting Information File 1, Appendix 6). All the observable $\pi \cdots \pi$ interactions were parallel-displaced (offset) $\pi$-stacking, and the distance values were within the range of the known values, whether determined from X-ray structures or calculated values $(3.2-4.0 \AA$ A) $[58,59,65]$.

Regarding the addition of diene $\mathbf{8 c}$ with the $\mathrm{N}$-methylmaleimide (7b), a $\pi \cdots \pi$ interaction is discarded. Nevertheless, the endo adduct $9 \mathrm{~g}$ was obtained as the major diastereoisomer (Table 2, entry 7). The calculated geometry at the endo TS reveals a plausible $\mathrm{C}_{\text {methyl }}-\mathrm{H} \cdots \pi$ interaction, based on the distance value $(2.537 \AA)$ to the benzene ring centroid. This interaction formed between one of the proton of the methyl group of $7 \mathbf{b}$ and the $N$-aryl ring of the pyrrole 8c (Table 7 and Figure $4 \mathrm{e}$ and Figure 5a,b). The aforementioned value matched well with that for the expected $\mathrm{C}_{\text {methyl }}-\mathrm{H} \cdots \pi$ interaction (2.5-3.4 $\AA$ and $2.79 \AA)[58,59,62,66]$ according to the calculations and the $\mathrm{X}$-ray calculated average taken from the Cambridge Structural Database (CSD) [76].

Interestingly, in the case of the reaction between diene $\mathbf{8 j}$ and $7 \mathbf{c}$, where the diene does not have an $\mathrm{N}$-benzyl group, the endo TS also displays a $\mathrm{C}_{\text {ethynyl }}-\mathrm{H} \cdots \pi$ interaction (2.530 $\AA$ ) between the acetylene proton of $\mathbf{8 j}$ and the $N$-phenyl ring of the $N$-phenylmaleimide (7c) (Table 7, and Figure $4 \mathrm{~d}$ and Figure 5c). Such an interaction may explain the greater stabilization of the endo approach to give $9 \mathbf{p}$ as the major isomer. Due to the scarce X-ray data from CSD about the distance of the $\mathrm{C}_{\text {ethynyl }}-\mathrm{H} \cdots \pi$ interaction [76], an average distance value (ca. 3.0 $\AA$ ) above the benzene ring centroid can be considered for the statistical distribution of the $\mathrm{C}_{\text {ethenyl }}-\mathrm{H} \cdots \pi$ interaction [76], which is longer than present calculated value.

On the other hand, the cycloaddition of the $N$-unsubstituted pyrrole 16a and $N$-phenylmaleimide (7c) proved to be highly endo diastereoselective as well (Table 2, entry 3 ). Hence, a supplementary $\mathrm{N}-\mathrm{H} \cdots \pi$ interaction between the $\mathrm{N}-\mathrm{H}$ bond of

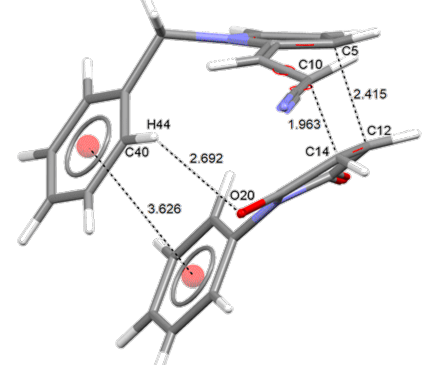

(a) TS of $8 b / 7 c$

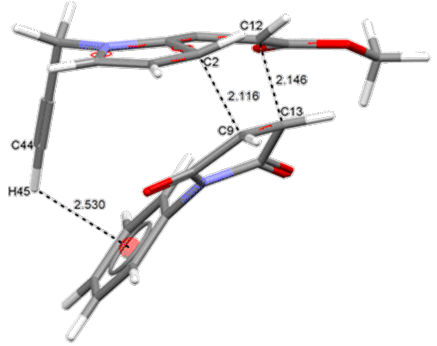

(d) TS of $8 \mathbf{j} / 7 \mathrm{c}$

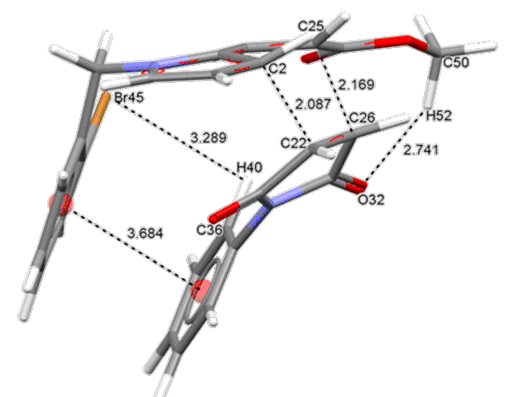

(b) TS of $8 c / 7 c$

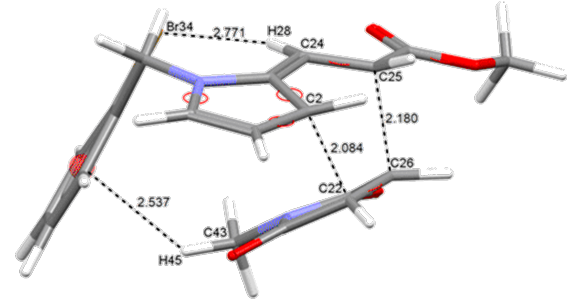

(e) TS of $8 c / 7 b$

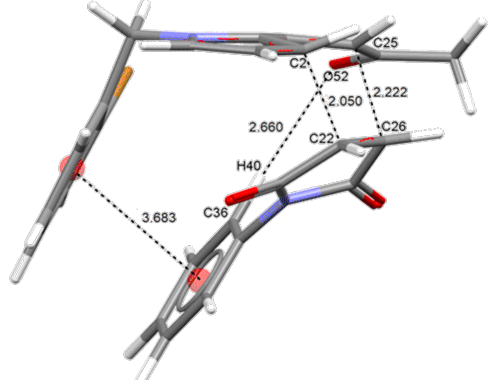

(c) TS of $8 \mathbf{g} / 7 \mathrm{c}$

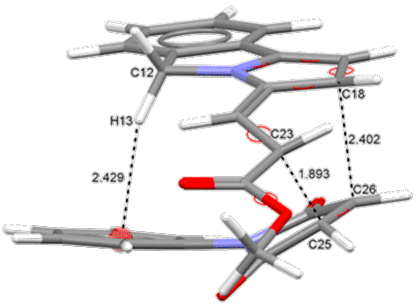

(f) TS of $18 a / 7 c$

Figure 4: M06-2X/6-31+G(d,p) Optimized geometry for each of the TSs of the Diels-Alder reactions of dienes $\mathbf{8 b}, \mathbf{8 c}, \mathbf{8 g}, \mathbf{8 j}$ and $\mathbf{1 8 a}$ with dienophiles 7b,c for the endo approach, showing the $\Pi \cdots \pi, \mathrm{C}-\mathrm{H} \cdots \pi, \mathrm{C}-\mathrm{H} \cdots \mathrm{OC}$ and $\mathrm{C}-\mathrm{H} \cdots \mathrm{Br}$ stacking interactions and their distances $(\AA)$ 
Table 7: Calculated [M06-2X/6-31+G(d,p)] NCls, including distances, angles and contact type from the ZPE-corrected geometry of each of the endo TSs of the Diels-Alder reactions of dienes $\mathbf{8 b}, \mathbf{8 c}, \mathbf{8 g}, \mathbf{8 j}$ and $\mathbf{1 8 \mathbf { a }}$ with dienophiles $7 \mathbf{b}, \mathbf{c} .^{{ }^{2}}$

\begin{tabular}{|c|c|c|c|c|}
\hline TS cycloaddends & interaction ${ }^{b}$ & distance $(\AA ̊)$ & angle $(\stackrel{\circ}{ })$ & contact type $^{c}$ \\
\hline $8 b / 7 c$ & $\mathrm{C}-\mathrm{H} \cdots \mathrm{O}$ & 2.962 & 131.89 & $\mathrm{D}-\mathrm{H} \cdots \mathrm{A}$ \\
\hline $8 b / 7 c$ & $\Pi \cdots \pi$ & 3.626 & 4.24 & $\begin{array}{l}\text { п-stacking } \\
\text { (parallel-displaced) }\end{array}$ \\
\hline $8 c / 7 c$ & $\mathrm{C}-\mathrm{H} \cdots \mathrm{O}$ & 2.741 & 119.78 & $\mathrm{D}-\mathrm{H} \cdots \mathrm{A}$ \\
\hline $8 c / 7 c$ & $\mathrm{C}-\mathrm{H} \cdots \mathrm{Br}^{\mathrm{d}}$ & 3.289 & 98.02 & $\mathrm{D}-\mathrm{H} \cdots \mathrm{A}$ \\
\hline $8 c / 7 c$ & $\Pi \cdots \pi$ & 3.684 & 16.02 & $\begin{array}{l}\text { ח-stacking } \\
\text { (parallel-displaced) }\end{array}$ \\
\hline $8 g / 7 c$ & $\mathrm{C}-\mathrm{H} \cdots \mathrm{O}^{\mathrm{e}}$ & 2.660 & 163.14 & $\mathrm{D}-\mathrm{H} \cdots \mathrm{A}$ \\
\hline $8 g / 7 c$ & $\pi \cdots \pi$ & 3.683 & 15.90 & $\begin{array}{l}\text { ח-stacking } \\
\text { (parallel-displaced) }\end{array}$ \\
\hline $8 \mathrm{j} / 7 \mathrm{c}$ & $\mathrm{C}_{\text {ethynyl}}-\mathrm{H} \cdots \Pi^{f}$ & 2.530 & 115.19 & $\mathrm{D}-\mathrm{H} \cdots \mathrm{A}$ \\
\hline $8 c / 7 b$ & $\mathrm{C}_{\text {methyl }}-\mathrm{H} \cdots \Pi^{\mathrm{g}}$ & 2.537 & 126.61 & $\mathrm{D}-\mathrm{H} \cdots \mathrm{A}$ \\
\hline $8 c / 7 b$ & $\mathrm{C}-\mathrm{H} \cdots \mathrm{Br}^{\mathrm{h}}$ & 2.771 & 160.54 & $\mathrm{D}-\mathrm{H} \cdots \mathrm{A}$ \\
\hline $18 a / 7 c$ & $\mathrm{C}_{\text {methylene }}-\mathrm{H} \cdots \pi^{\mathrm{i}}$ & 2.429 & 154.71 & $\mathrm{D}-\mathrm{H} \cdots \mathrm{A}$ \\
\hline
\end{tabular}

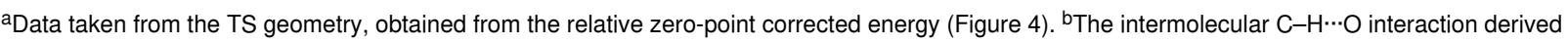
from the proton of the benzene ring or the proton of the methoxy group of the ester of the diene and a carbonyl oxygen of the dienophile. ${ }^{c} D=$ donat- $^{\circ}$ ing atom; $\mathrm{A}=$ acceptor atom or aromatic ring. ${ }^{\mathrm{d}}$ The intermolecular $\mathrm{C}-\mathrm{H} \cdots \mathrm{Br}$ derived from the aryl proton of $7 \mathrm{c}$ and the bromine atom of diene $8 \mathrm{c}$. ${ }^{\mathrm{e}}$ The intermolecular $\mathrm{C}-\mathrm{H} \cdots \mathrm{O}$ interaction derived from the proton of the benzene ring of $7 \mathrm{c}$ and of the carbonyl oxygen of diene $\mathbf{8 g} .{ }^{\top}$ The $\mathrm{C}-\mathrm{H} \cdots \cdots$ interaction derived from the proton of the terminal acetylene of diene $8 \mathbf{j}$ and the benzene ring of $7 \mathrm{c}$. 9The $\mathrm{C}-\mathrm{H} \cdots \Pi$ interaction derived from the proton of the $\mathrm{N}$-methyl group of $\mathbf{7 b}$ and the benzene ring of $\mathbf{8 c}$. ${ }^{\mathrm{h}}$ The intramolecular $\mathrm{C}-\mathrm{H} \cdots \mathrm{Br}$ interaction derived from the vinylic proton and the bromine atom of diene $\mathbf{8 c}$. 'The $\mathrm{C}-\mathrm{H} \cdots \pi$ interaction derived from the proton of methylene of the pyrrolizine moiety of diene 18a and the benzene ring of 7c.

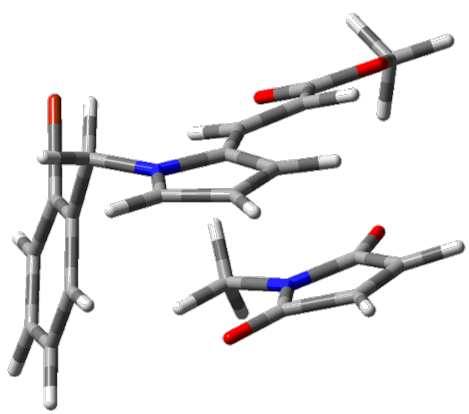

(a)

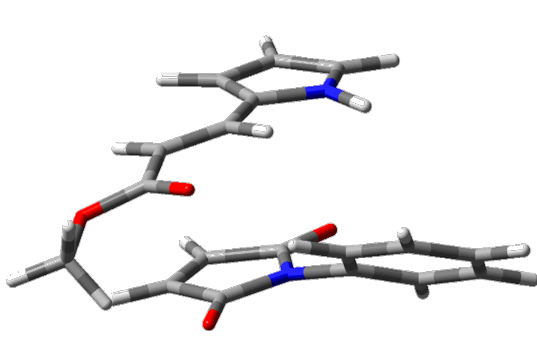

(d)

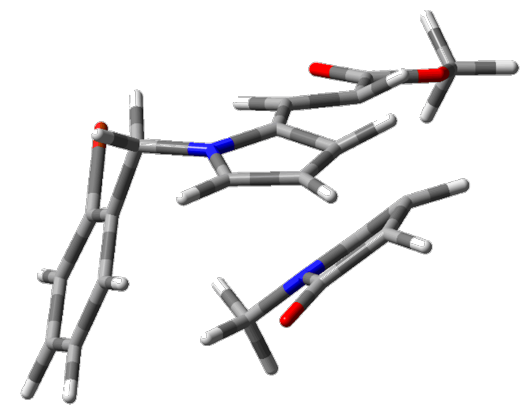

(b)

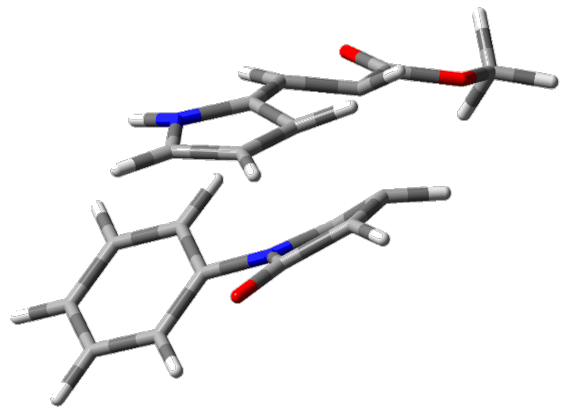

(e)

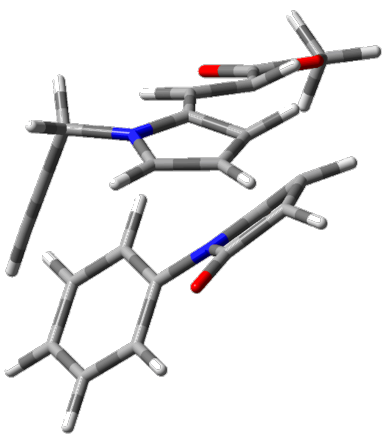

(c)

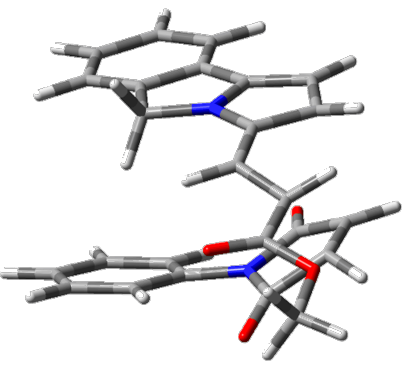

(f)

Figure 5: M06-2X/6-31+G(d,p) Optimized geometry of the endo SCs (a) and TSs (b) for the Diels-Alder reaction of diene $8 \mathbf{c}$ and dienophile $\mathbf{7 b}$, the endo TSs (c) of the reaction of $\mathbf{8 j}$ and $\mathbf{7 c}$, the endo approach of the SC (d) and TS (e) for the cycloaddition of 16a and 7c, and the endo TS (f) for the cycloaddition of $18 \mathrm{a}$ and $7 \mathrm{c}$. 
pyrrole 16a and the $N$-phenyl ring of 7c may be involved at the SC and TS to improve the stability of such an approach (Figure 5d,e). Despite the fact that this interaction was not clearly detected at the endo TS, an incipient $\mathrm{N}-\mathrm{H} \cdots \pi$ interaction seems to be present (Supporting Information File 1, Appendix $6)$.

The preference of the endo selectivity for the cycloaddition of the isoindolyl diene 18a and 7c can be also accounted for by a perceptible $\mathrm{C}_{\text {methylene }}-\mathrm{H} \cdots \pi$ interaction (2.429 $\AA$ to the benzene ring centroid) (Table 7 and Figure 4f) between a proton of the C-5 methylene group of the pyrrolo[2,1-a]isoindole ring of 18a and the $N$-phenyl ring of $7 \mathbf{c}$ (Figure 5f). Additional hydrogen bonding, which was found for these and the other cycloaddends between a proton of the benzene ring of the diene and an oxygen atom of the dienophile (Table 7), also stabilize the endo TS.

Therefore, this theoretical study indicated that the non-covalent $\pi \cdots \pi$ and $\mathrm{C}-\mathrm{H} \cdots \pi$ interactions control the endo selectivity in the Diels-Alder cycloadditions. Since experimental and theoretical results have demonstrated that the nature of the $\mathrm{C}-\mathrm{H} \cdots \pi$ interaction mainly depends on the dispersion interactions [64,67,77], these are probably not only at the origin of the endo stereoselectivity of the present cycloadditions, but also involved in the general endo-Alder rule [53]. The latter rule has been traditionally attributed to secondary orbital interactions (SOI) [78-80], although a controversy exists due to the lack of solid evidence for this hypothesis [81]. Consequently, a lot of research has been carried out to provide additional insights into the factors controlling the endo outcome [53,82-85], documenting in some cases a key role of NCIs in the preferential stereocontrol [86].

\section{Conclusion}

The Diels-Alder reaction of $N$-substituted-2-vinylpyrroles $\mathbf{8 a - j}$ and $N$-unsubstituted-2-vinylpyrroles $\mathbf{1 6 a}, \mathbf{b}$ with maleimides $\mathbf{7 b}, \mathbf{c}$ proved to be highly endo diastereoselective. This selectivity turned out to be significant in the case of vinyl benzopyrrolizine 18a as well. The consecutive $\operatorname{Pd}(0)$ cross-coupling reaction of some of the Diels-Alder adducts allowed for the synthesis of a numerous series of pyrrolizine-containing polycycles, including isoindolo[2,1- $a$ ]indole-based tetrahydro and fully aromatic pentacycles. These findings reveal the synthetic value of 2-formylpyrrole (13a) for the diastereo- and regioselective construction of isoindolo- and pyrrolo-fused polycyclic indoles. Theoretical calculations suggest that the greater stability of the endo TSs in the Diels-Alder cycloadditions is associated with NCIs between the $N$-substituents of both cycloaddends. These interactions are also involved in the case of pyrrolo[2,1- $a$ ] isoindole 18a with dienophile 7c.

\section{Supporting Information}

Appendix 1: Energies and coefficients of the Frontier Molecular Orbitals [HF/6-31G(d,p)] of dienes $\mathbf{8 b}, \mathbf{8 c}$ and 8g, and dienophile 7c. Appendix 2: Relative zero point-corrected energies of the SCs, TSs, and ADs located on the potential surfaces of the Diels-Alder reactions of dienes $8 \mathbf{b}, 8 \mathbf{c}, 8 \mathrm{gg}, 8 \mathbf{j}, \mathbf{1 6 a}$, and 18a, and dienophiles $7 \mathbf{b}, \mathbf{c}$. Appendix 3: X-ray crystallographic structures of $9 \mathrm{~m}$ and 10m. Appendix 4: M06-2X/6-31+G(d,p) relative Gibbs free energies $(\mathrm{kcal} / \mathrm{mol})$ of the stationary points in the Diels-Alder cycloadditions of dienes $8 \mathbf{b}, 8 \mathbf{c}, 8 \mathrm{~g}, \mathbf{8 j}, \mathbf{1 6 a}$, and 18a, and dienophiles 7b,c. Appendix 5: Calculation [M06-2X/6-31+G(d,p)] of Z-matrices of the optimized geometries of the SCs, TSs, and ADs of the Diels-Alder cycloadditions of dienes $8 \mathbf{b}, 8 \mathbf{c}, 8 \mathrm{~g}, 8 \mathbf{j}, 16 \mathbf{a}$, and $18 \mathbf{a}$, and dienophiles 7b,c. Appendix 6: Calculation [M06-2X/6-31+G(d,p)] of the NCIs, including distances, angles and contact type from the ZPE-corrected geometries of the endo TSs of the Diels-Alder reactions of dienes $\mathbf{8 b}$,

8c, 8g, 8j and 18a and dienophiles 7b,c. Appendix 7: Experimental section. Appendix 8: ${ }^{1} \mathrm{H}$ and ${ }^{13} \mathrm{C}$ NMR spectra for all new compounds.

\section{Supporting Information File 1}

Experimental and analytical data, X-ray crystallographic structures, NMR-spectra and all calculated data.

[https://www.beilstein-journals.org/bjoc/content/ supplementary/1860-5397-16-113-S1.pdf]

\section{Acknowledgments}

We thank E. Labarrios, A. Jerezano and CNMN-IPN for their help in spectrometric measurements, and Bruce A. Larsen for proofreading.

\section{Funding}

J.T. acknowledges SIP/IPN (Grants 20140858, 20150917, 20160791, 20170902, 20180198, 20195228 and 20200227) and Consejo Nacional de Ciencia y Tecnología (CONACYT, Mexico) (Grants 178319, A1-S-17131 and 300520) for financial support. C.E.-H. and A.A.C.-D. are grateful to CONACYT for a grant to purchase the NMR instrument (INFR-2014-01226114). E.I.M.-M. greatly appreciate the support given by the SEP through the NPTC program (UACOAH-PTC-498). C.H.E. and E.I.M.-M. are beholden to CONACYT for awarding them graduate scholarships, and also thank SIP/IPN (BEIFI) and the Ludwig K. Hellweg Foundation for scholarship complements. F.D. and J.T. are fellows of the EDI-IPN and COFAA-IPN programs. 


\section{ORCID ${ }^{\circledR}$ iDs}

Carlos H. Escalante - https://orcid.org/0000-0002-4625-6883 Eder I. Martínez-Mora - https://orcid.org/0000-0003-4850-8279 Carlos Espinoza-Hicks - https://orcid.org/0000-0002-9947-8439 Alejandro A. Camacho-Dávila - https://orcid.org/0000-0001-5351-584X Francisco Delgado - https://orcid.org/0000-0003-4952-4684 Joaquín Tamariz - https://orcid.org/0000-0002-0600-3857

\section{References}

1. Mantovani, S. M.; Moore, B. S. J. Am. Chem. Soc. 2013, 135 , 18032-18035. doi:10.1021/ja409520v

2. Belal, A.; El-Gendy, B. E.-D. M. Bioorg. Med. Chem. 2014, 22, 46-53. doi:10.1016/j.bmc.2013.11.040

3. Robertson, J.; Stevens, K. Nat. Prod. Rep. 2014, 31, 1721-1788. doi:10.1039/c4np00055b

4. Tamariz, J.; Burgueño-Tapia, E.; Vázquez, M. A.; Delgado, F. Pyrrolizidine Alkaloids. In The Alkaloids; Knölker, H.-J., Ed.; Academic Press: Cambridge, U.S.A., 2018; Vol. 80, pp 1-331. doi:10.1016/s1099-4831(18)30022-1

5. Robertson, J.; Stevens, K. Nat. Prod. Rep. 2017, 34, 62-89. doi:10.1039/c5np00076a

6. Lage, S.; Martínez-Estíbalez, U.; Sotomayor, N.; Lete, E. Adv. Synth. Catal. 2009, 351, 2460-2468. doi:10.1002/adsc.200900368

7. Lorton, C.; Voituriez, A. Eur. J. Org. Chem. 2019, 5133-5150. doi:10.1002/ejoc.201900626

8. Enders, D.; Wang, C.; Raabe, G. Synthesis 2009, 4119-4124. doi:10.1055/s-0029-1217069

9. Hong, L.; Sun, W.; Liu, C.; Wang, L.; Wang, R. Chem. - Eur. J. 2010, 16, 440-444. doi:10.1002/chem.200902638

10. Gorre, R.; Enagandhula, D.; Balasubramanian, S.; Akondi, S. M. Org. Biomol. Chem. 2020, 18, 1354-1358. doi:10.1039/c9ob02730k

11. Wang, H.; Wu, X.-F. Org. Lett. 2019, 21, 5264-5268. doi:10.1021/acs.orglett.9b01868

12. Fernandez, L. S.; Sykes, M. L.; Andrews, K. T.; Avery, V. M. Int. J. Antimicrob. Agents 2010, 36, 275-279. doi:10.1016/j.jjantimicag.2010.05.008

13. Bass, P. D.; Gubler, D. A.; Judd, T. C.; Williams, R. M. Chem. Rev. 2013, 113, 6816-6863. doi:10.1021/cr3001059

14. Alvarez-Mico, X.; Jensen, P. R.; Fenical, W.; Hughes, C. C. Org. Lett. 2013, 15, 988-991. doi:10.1021/ol303374e

15. Sharma, V.; Kumar, P.; Pathak, D. J. Heterocycl. Chem. 2010, 491, 491-502. doi:10.1002/jhet.349

16. Thanikachalam, P. V.; Maurya, R. K.; Garg, V.; Monga, V. Eur. J. Med. Chem. 2019, 180, 562-612. doi:10.1016/j.ejmech.2019.111680

17. Shiri, M. Chem. Rev. 2012, 112, 3508-3549. doi:10.1021/cr2003954

18. Chen, J.-B.; Jia, Y.-X. Org. Biomol. Chem. 2017, 15, 3550-3567. doi:10.1039/c7ob00413c

19. Marchese, A. D.; Lind, F.; Mahon, Á. E.; Yoon, H.; Lautens, M. Angew. Chem., Int. Ed. 2019, 58, 5095-5099. doi:10.1002/anie.201900659

20. Enders, D.; Greb, A.; Deckers, K.; Selig, P.; Merkens, C. Chem. - Eur. J. 2012, 18, 10226-10229. doi:10.1002/chem.201201493

21. Laha, J. K.; Dayal, N.; Singh, S.; Bhimpuria, R. Eur. J. Org. Chem. 2014, 5469-5475. doi:10.1002/ejoc.201402395

22. Speck, K.; Magauer, T. Beilstein J. Org. Chem. 2013, 9, 2048-2078. doi:10.3762/bjoc.9.243
23. Bornadiego, A.; Díaz, J.; Marcos, C. F. J. Org. Chem. 2019, 84, 7426-7433. doi:10.1021/acs.joc.9b00381

24. Hudkins, R. L.; Johnson, N. W.; Angeles, T. S.; Gessner, G. W.; Mallamo, J. P. J. Med. Chem. 2007, 50, 433-441. doi:10.1021/jm051074u

25. Sánchez, C.; Méndez, C.; Salas, J. A. Nat. Prod. Rep. 2006, 23, 1007-1045. doi:10.1039/b601930g

26. Schmidt, A. W.; Reddy, K. R.; Knölker, H.-J. Chem. Rev. 2012, 112, 3193-3328. doi:10.1021/cr200447s

27. Janosik, T.; Rannug, A.; Rannug, U.; Wahlström, N.; Slätt, J.; Bergman, J. Chem. Rev. 2018, 118, 9058-9128. doi:10.1021/acs.chemrev.8b00186

28. Liu, R.-R.; Wang, Y.-G.; Li, Y.-L.; Huang, B.-B.; Liang, R.-X.; Jia, Y.-X. Angew. Chem., Int. Ed. 2017, 56, 7475-7478. doi:10.1002/anie.201703833

29. Petrone, D. A.; Kondo, M.; Zeidan, N.; Lautens, M. Chem. - Eur. J. 2016, 22, 5684-5691. doi:10.1002/chem.201600118

30. Zeidan, N.; Beisel, T.; Ross, R.; Lautens, M. Org. Lett. 2018, 20 , 7332-7335. doi:10.1021/acs.orglett.8b03310

31. Ohno, M.; Shimizu, S.; Eguchi, S. Tetrahedron Lett. 1990, 31 , 4613-4616. doi:10.1016/s0040-4039(00)97689-5

32. Noland, W. E.; Lanzatella, N. P.; Venkatraman, L.; Anderson, N. F.; Gullickson, G. C. J. Heterocycl. Chem. 2009, 46, 1154-1176. doi:10.1002/jhet.198

33. Xiao, D.; Ketcha, D. M. J. Heterocycl. Chem. 1995, 32, 499-503. doi:10.1002/jhet.5570320220

34. Hosmane, R. S.; Hiremath, S. P.; Schneller, S. W J. Chem. Soc., Perkin Trans. 1 1973, 2450-2453. doi:10.1039/p19730002450

35. Noland, W. E.; Lee, C. K.; Bae, S. K.; Chung, B. Y.; Hahn, C. S.; Kim, K. J. J. Org. Chem. 1983, 48, 2488-2491. doi:10.1021/jo00163a011

36. Yoshida, K.; Hayashi, K.; Yanagisawa, A. Org. Lett. 2011, 13, 4762-4765. doi:10.1021/ol201510u

37. Reddy, C. R.; Valleti, R. R.; Sathish, P. J. Org. Chem. 2017, 82, 2345-2354. doi:10.1021/acs.joc.6b02637

38. Zhao, Y.; Yuan, Y.; Xu, M.; Zheng, Z.; Zhang, R.; Li, Y. Org. Biomol. Chem. 2017, 15, 6328-6332. doi:10.1039/c7ob01516j

39. Noland, W. E.; Lanzatella, N. P.; Dickson, R. R.; Messner, M. E.; Nguyen, H. H. J. Heterocycl. Chem. 2013, 50, 795-808. doi:10.1002/jhet.1571

40. Quiroz-Florentino, H.; Hernández-Benitez, R. I.; Aviña, J. A.; Burgueño-Tapia, E.; Tamariz, J. Synthesis 2011, 1106-1112. doi:10.1055/s-0030-1258455

41. Martínez-Mora, E. I.; Caracas, M. A.; Escalante, C. H.; Madrigal, D. A.; Quiroz-Florentino, H.; Delgado, F.; Tamariz, J. J. Mex. Chem. Soc. 2017, 60, 23-33. doi:10.29356/jmcs.v60i1.67

42. Martínez-Mora, E. I.; Caracas, M. A.; Escalante, C. H.; Espinoza-Hicks, C.; Quiroz-Florentino, H.; Delgado, F.; Tamariz, J. Synthesis 2016, 48, 1055-1068. doi:10.1055/s-0035-1561331

43. CCDC-1987245 (for 9m) and -1987244 (for $10 \mathrm{~m}$ ) contain the supplementary crystallographic data for this paper. These data can be obtained free of charge from The Cambridge Crystallographic Data Centre via https://www.ccdc.cam.ac.uk/data_request/cif.

44. Lafrance, M.; Rowley, C. N.; Woo, T. K.; Fagnou, K. J. Am. Chem. Soc. 2006, 128, 8754-8756. doi:10.1021/ja062509।

45. Bautista, R.; Montoya, P. A.; Rebollar, A.; Burgueño, E.; Tamariz, J. Molecules 2013, 18, 10334-10351. doi:10.3390/molecules180910334 46. Wurche, F.; Sicking, W.; Sustmann, R.; Klärner, F.-G.; Rüchardt, C. Chem. - Eur. J. 2004, 10, 2707-2721. doi:10.1002/chem.200305686 
47. Mashraqui, S.; Keehn, P. Synth. Commun. 1982, 12, 637-645. doi:10.1080/00397918208061895

48. Zhao, Y.; Truhlar, D. G. J. Chem. Theory Comput. 2007, 3, 289-300. doi:10.1021/ct6002719

49. Hohenstein, E. G.; Chill, S. T.; Sherrill, C. D. J. Chem. Theory Comput. 2008, 4, 1996-2000. doi:10.1021/ct800308k

50. Black, K.; Liu, P.; Xu, L.; Doubleday, C.; Houk, K. N. Proc. Natl. Acad. Sci. U. S. A. 2012, 109, 12860-12865. doi:10.1073/pnas.1209316109

51. Espinoza-Hicks, C.; Montoya, P.; Bautista, R.; Jiménez-Vázquez, H. A.; Rodríguez-Valdez, L. M.; Camacho-Dávila, A. A.; Cossío, F. P.; Delgado, F.; Tamariz, J. J. Org. Chem. 2018, 83, 5347-5364. doi:10.1021/acs.joc.7b02344

52. Gaussian 09, Revision A.1; Gaussian, Inc. : Wallingford CT, 2009.

53. Ramírez-Gualito, K.; López-Mora, N.; Jiménez-Vázquez, H. A.; Tamariz, J.; Cuevas, G. J. Mex. Chem. Soc. 2013, 57, 267-275. doi:10.29356/jmcs.v57i4.189

54. Argile, A.; Ruasse, M.-F. Tetrahedron Lett. 1980, 21, 1327-1330. doi:10.1016/s0040-4039(00)74567-9

55. Shaik, S.; Epiotis, N. D. J. Am. Chem. Soc. 1978, 100, 18-29. doi:10.1021/ja00469a003

56. Branchadell, V.; Oliva, A.; Bertrán, J. J. Mol. Struct.: THEOCHEM 1986, 138, 117-120. doi:10.1016/0166-1280(86)87014-2

57. Fleming, I. Molecular Orbitals and Organic Chemical Reactions; John Wiley \& Sons, Ltd: Chichester, United Kingdom, 2010. doi:10.1002/9780470689493 ISBN 978-0-470-746585.

58. Janiak, C. J. Chem. Soc., Dalton Trans. 2000, 3885-3896. doi:10.1039/b003010o

59. Salonen, L. M.; Ellermann, M.; Diederich, F. Angew. Chem., Int. Ed. 2011, 50, 4808-4842. doi:10.1002/anie.201007560

60. Mati, I. K.; Cockroft, S. L. Chem. Soc. Rev. 2010, 39, 4195-4205. doi:10.1039/b822665m

61. Wheeler, S. E.; Bloom, J. W. G. J. Phys. Chem. A 2014, 118, 6133-6147. doi:10.1021/jp504415p

62. Suresh, C. H.; Mohan, N.; Vijayalakshmi, K. P.; George, R.; Mathew, J. M. J. Comput. Chem. 2009, 30, 1392-1404. doi:10.1002/jcc.21162

63. Takahashi, O.; Kohno, Y.; Nishio, M. Chem. Rev. 2010, 110, 6049-6076. doi:10.1021/cr100072x

64. Tsuzuki, S.; Fujii, A. Phys. Chem. Chem. Phys. 2008, 10, 2584-2594. doi:10.1039/b718656h

65. Macias, A. T.; MacKerell, A. D., Jr. J. Comput. Chem. 2005, 26 , 1452-1463. doi:10.1002/jcc.20281

66. Ringer, A. L.; Figgs, M. S.; Sinnokrot, M. O.; Sherrill, C. D. J. Phys. Chem. A 2006, 110, 10822-10828. doi:10.1021/jp062740I

67. Cabaleiro-Lago, E. M.; Rodríguez-Otero, J.; Peña-Gallego, Á. J. Phys. Chem. A 2008, 112, 6344-6350. doi:10.1021/jp8021979

68. Zhang, X.; Lu, G.-p.; Xu, Z.-b.; Cai, C. ACS Sustainable Chem. Eng. 2017, 5, 9279-9285. doi:10.1021/acssuschemeng.7b02241

69. Johnson, E. R.; Keinan, S.; Mori-Sánchez, P.; Contreras-García, J.; Cohen, A. J.; Yang, W. J. Am. Chem. Soc. 2010, 132, 6498-6506. doi:10.1021/ja100936w

70. Quiñonero, D.; Frontera, A.; Escudero, D.; Ballester, P.; Costa, A.; Deyà, P. M. Theor. Chem. Acc. 2008, 120, 385-393. doi:10.1007/s00214-008-0416-9

71. Cayzer, T. N.; Paddon-Row, M. N.; Sherburn, M. S. Eur. J. Org. Chem. 2003, 4059-4068. doi:10.1002/ejoc.200300414

72. Mehranfar, A.; Izadyar, M.; Khavani, M.; Housaindokht, M. R. Int. J. Quantum Chem. 2019, 119, e25878. doi:10.1002/qua.25878
73. Krenske, E. H.; Houk, K. N. Acc. Chem. Res. 2013, 46, 979-989. doi:10.1021/ar3000794

74. Zhang, H.; Piacham, T.; Drew, M.; Patek, M.; Mosbach, K.; Ye, L. J. Am. Chem. Soc. 2006, 128, 4178-4179. doi:10.1021/ja057781u

75. Kumar, G. S.; Satheeshkumar, R.; Kaminsky, W.; Platts, J.; Prasad, K. J. R. Tetrahedron Lett. 2014, 55, 5475-5480. doi:10.1016/j.tetlet.2014.08.036

76. Mooibrock, T. J.; Gamez, P. CrystEngComm 2012, 14, 8462-8467. doi:10.1039/c2ce26205c

77. Riley, K. E.; Pitoňák, M.; Černý, J.; Hobza, P. J. Chem. Theory Comput. 2010, 6, 66-80. doi:10.1021/ct900376r

78. Wannere, C. S.; Paul, A.; Herges, R.; Houk, K. N.; Schaefer, H. F., III; Schleyer, P. v. R. J. Comput. Chem. 2007, 28, 344-361. doi:10.1002/jcc.20532

79. Levandowski, B. J.; Houk, K. N. J. Am. Chem. Soc. 2016, 138, 16731-16736. doi:10.1021/jacs.6b10463

80. Arrieta, A.; Cossío, F. P.; Lecea, B. J. Org. Chem. 2001, 66, 6178-6180. doi:10.1021/jo0158478

81. García, J. I.; Mayoral, J. A.; Salvatella, L. Acc. Chem. Res. 2000, 33, 658-664. doi:10.1021/ar0000152

82. García, J. I.; Mayoral, J. A.; Salvatella, L. Eur. J. Org. Chem. 2005, 85-90. doi:10.1002/ejoc.200400424

83. Fernández, I.; Bickelhaupt, F. M. J. Comput. Chem. 2014, 35 , 371-376. doi:10.1002/jcc.23500

84. Sakata, K.; Fujimoto, H. Eur. J. Org. Chem. 2016, 4275-4278. doi:10.1002/ejoc.201600676

85. Levandowski, B. J.; Zou, L.; Houk, K. N. J. Comput. Chem. 2016, 37, 117-123. doi:10.1002/jcc.24191

86. Gallardo-Fuentes, S.; Lezana, N.; Lühr, S.; Galdámez, A.; Vilches-Herrera, M. J. Org. Chem. 2019, 84, 10825-10831. doi:10.1021/acs.joc.9b01390

\section{License and Terms}

This is an Open Access article under the terms of the Creative Commons Attribution License (http://creativecommons.org/licenses/by/4.0). Please note that the reuse, redistribution and reproduction in particular requires that the authors and source are credited.

The license is subject to the Beilstein Journal of Organic Chemistry terms and conditions: (https://www.beilstein-journals.org/bjoc)

The definitive version of this article is the electronic one which can be found at: $\underline{\text { doi: } 10.3762 / \text { bjoc. } 16.113}$ 